Supporting information for

\title{
Transformation of Formazanate at Nickel(II) centers to give a singly reduced Nickel complex with azo-iminate radical ligands and its reactivity towards dioxygen
}

Deniz Ar, Alexander F. R. Kilpatrick, Beatrice Cula, Christian Herwig, Christian Limberg*

Table of Contents

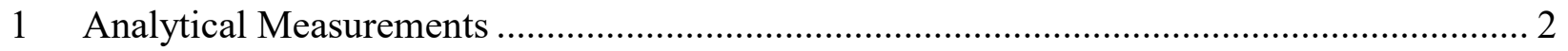

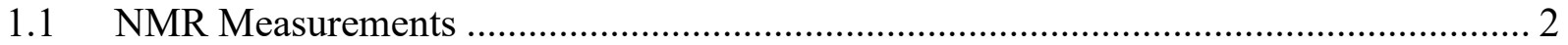

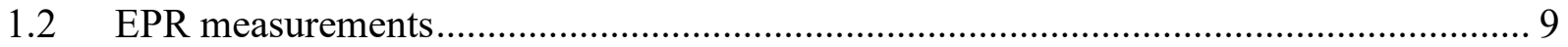

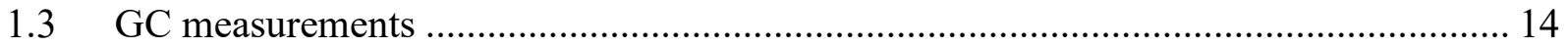

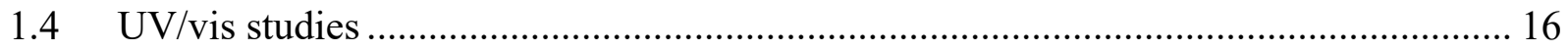

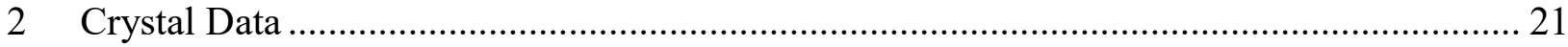

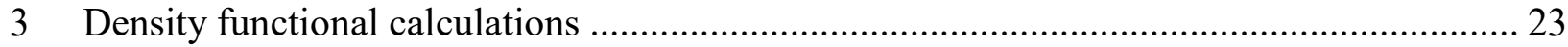

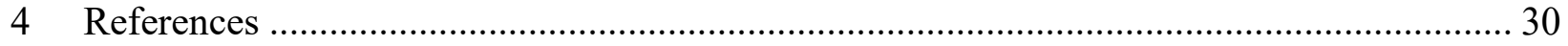




\section{Analytical Measurements}

\subsection{NMR Measurements}

\subsubsection{Reaction of $\mathrm{PPh}_{3}$ with $\mathrm{O}_{2}$ in presence of 2}

$5.0 \mathrm{mg}$ of compound 2 (1 eq., $5.6 \mu \mathrm{mol})$ with $8.8 \mathrm{mg}$ of $\mathrm{PPh}_{3}(6$ eq., $33.6 \mu \mathrm{mol})$ were dissolved in $0.6 \mathrm{~mL} \mathrm{C}_{6} \mathrm{D}_{6}$ and treated with $\mathrm{O}_{2}$ in a NMR tube sealed with a Youngs tap by replacing the argon atmosphere with an $\mathrm{O}_{2}$ atmosphere. For comparison, the same amount of $\mathrm{PPh}_{3}$ was treated with $\mathrm{O}_{2}$ in $\mathrm{C}_{6} \mathrm{D}_{6}$ without compound 2 . After $14 \mathrm{~h}$ the conversion was complete and 2 equivalents of $\mathrm{PPh}_{3}$ were found to have been converted into $\mathrm{OPPh}_{3}$, while no conversion was observed via ${ }^{31} \mathrm{P}$ NMR, when 2 was not present.
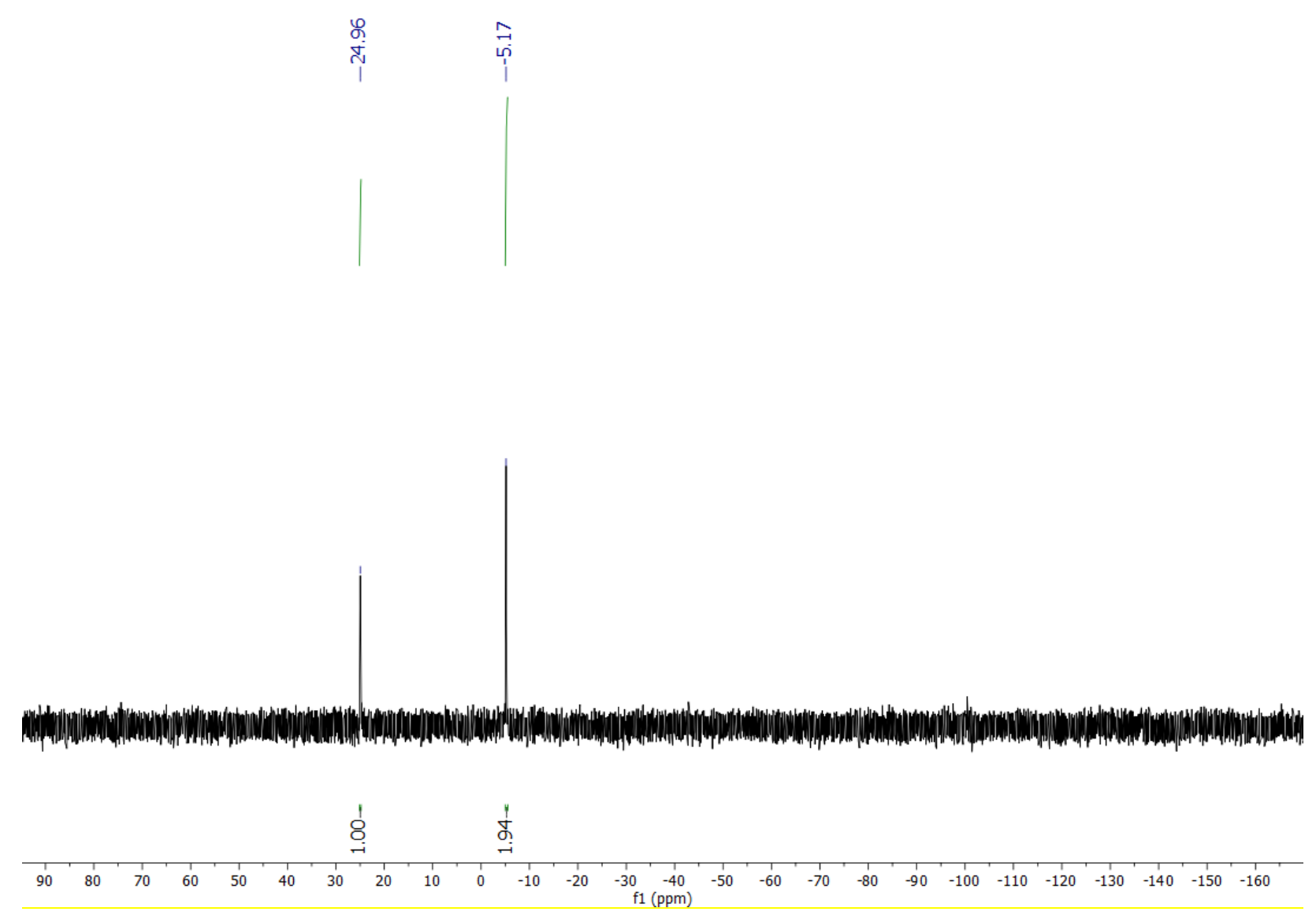

Figure S1. ${ }^{31} \mathrm{P}$ NMR spectrum of the reaction of 2 (1 equivalent) and $\mathrm{O}_{2}$ with $\mathrm{PPh}_{3}$ (6 equivalents) at r.t. in $\mathrm{C}_{6} \mathrm{D}_{6}$. 


\subsection{2 ${ }^{1} \mathrm{H}$ and ${ }^{13} \mathrm{C}$ NMR of complex 1 and 3}

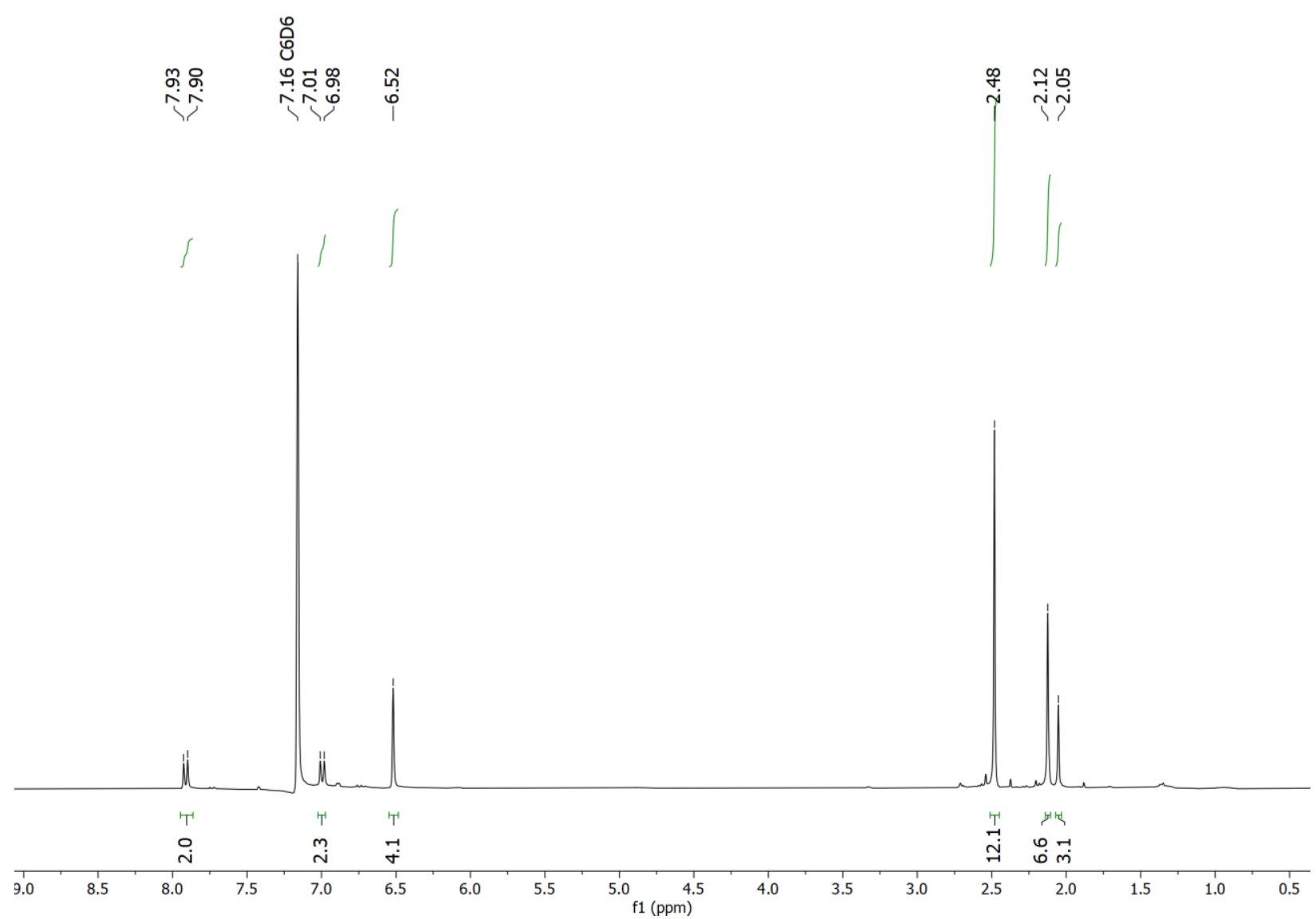

Figure S2. ${ }^{1} \mathrm{H}$ NMR spectrum of $\mathbf{1}$ in $\mathrm{C}_{6} \mathrm{D}_{6}$. 


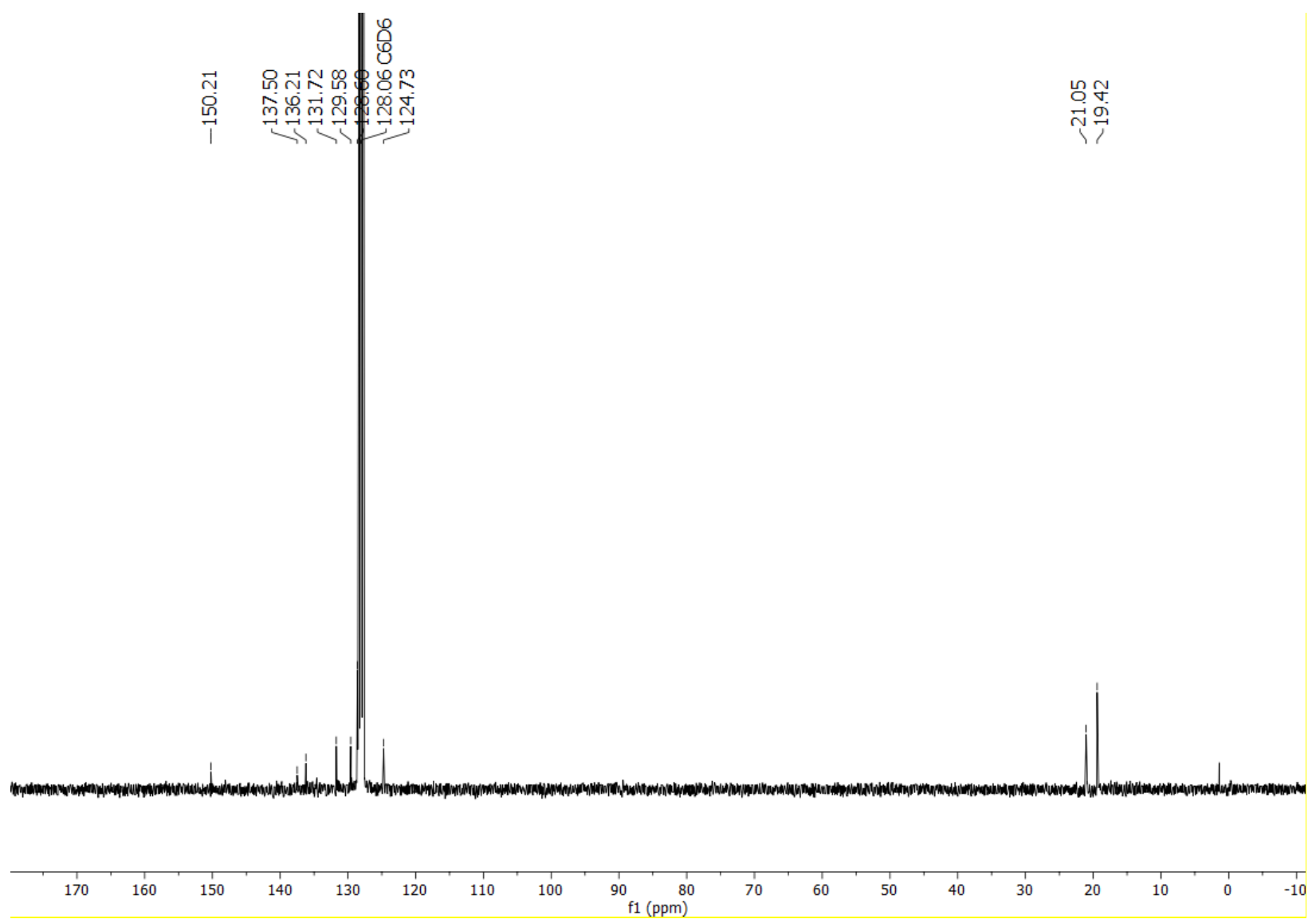

Figure S3. ${ }^{13} \mathrm{C}$ NMR spectrum of 1 dissolved in $\mathrm{C}_{6} \mathrm{D}_{6}$, 


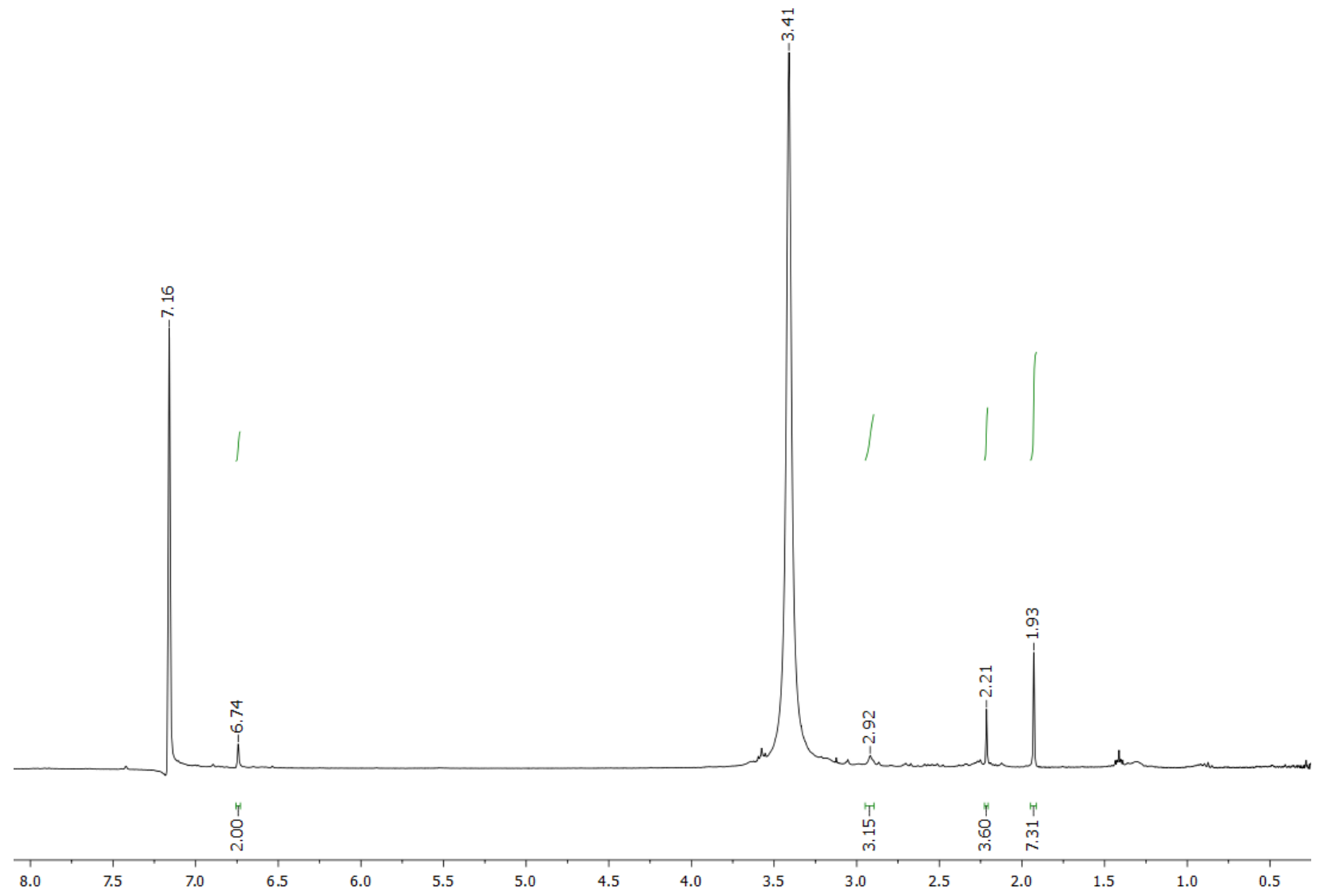

Figure S4. ${ }^{1} \mathrm{H}$ NMR spectrum recorded after the reaction of 1 with $\mathrm{KC}_{8}$ and 18 -crown-6 in $\mathrm{C}_{6} \mathrm{D}_{6}$ in an NMR tube. 


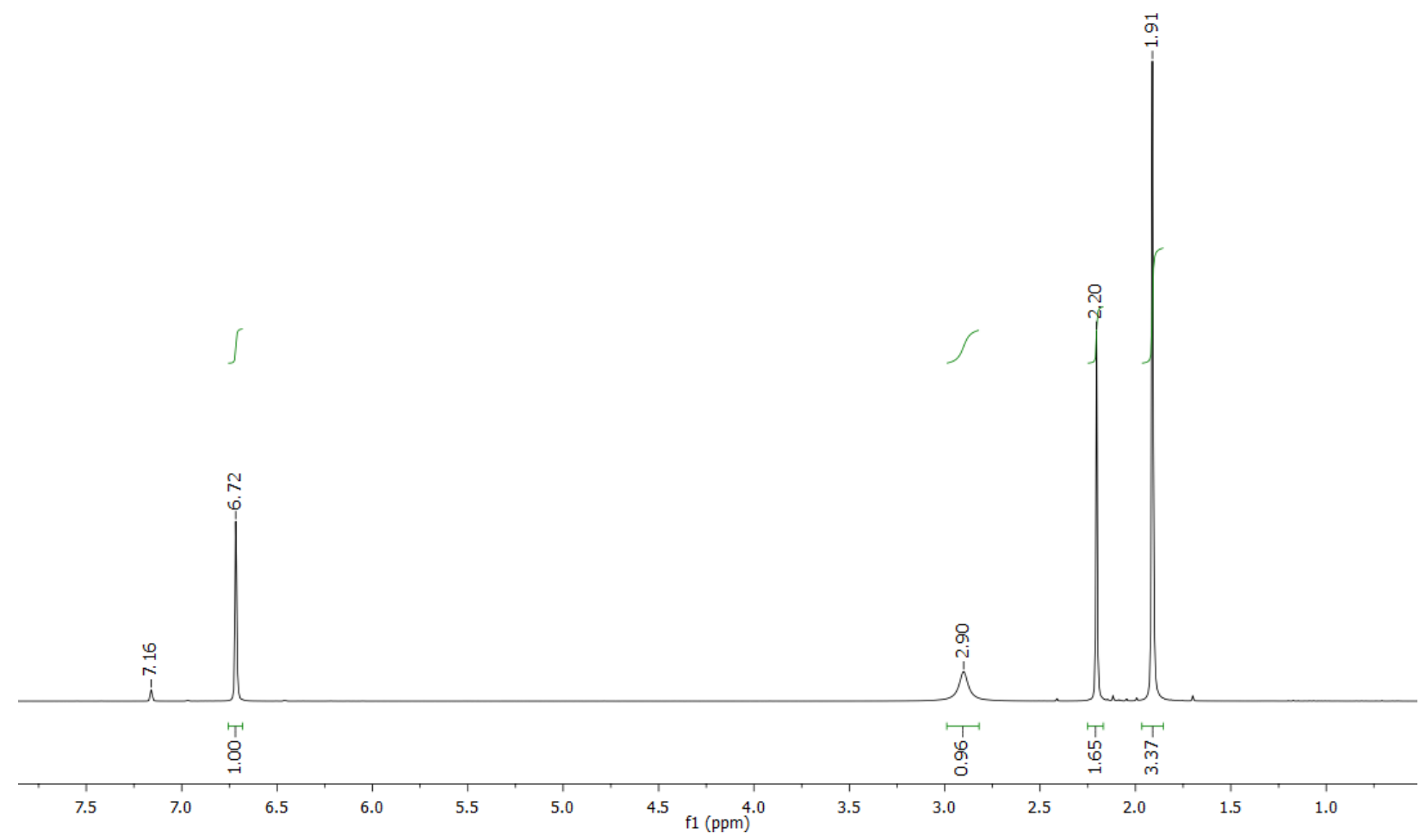

Figure S5. ${ }^{1} \mathrm{H}$ NMR spectrum of mesitylaniline $(0.03 \mathrm{~mL}, 213.7 \mu \mathrm{mol})$ dissolved in $\mathrm{C}_{6} \mathrm{D}_{6}$. 


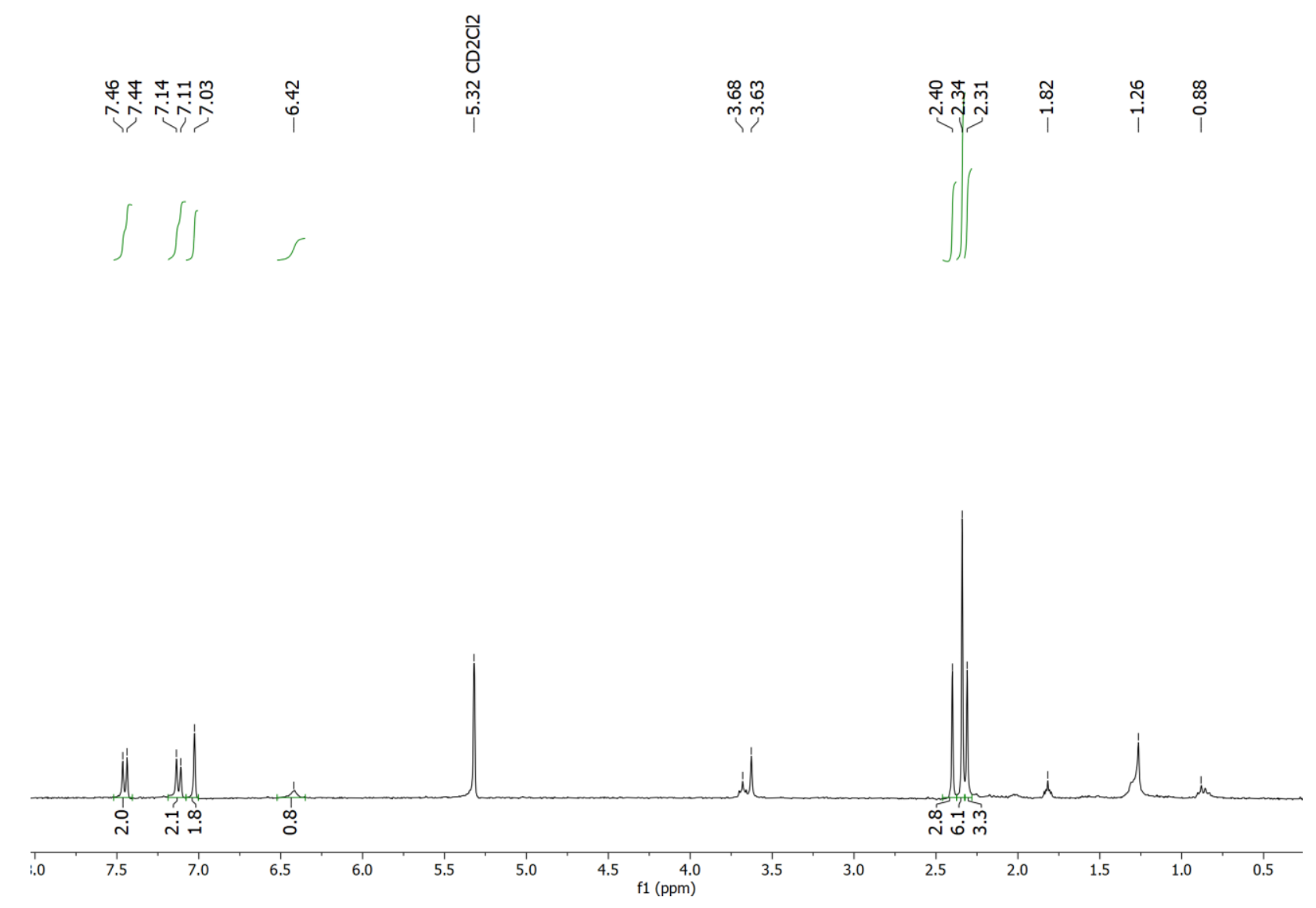

Figure S6. ${ }^{1} \mathrm{H}$ NMR spectrum of $\mathbf{3}$ dissolved in $\mathrm{CD}_{2} \mathrm{Cl}_{2}$. 


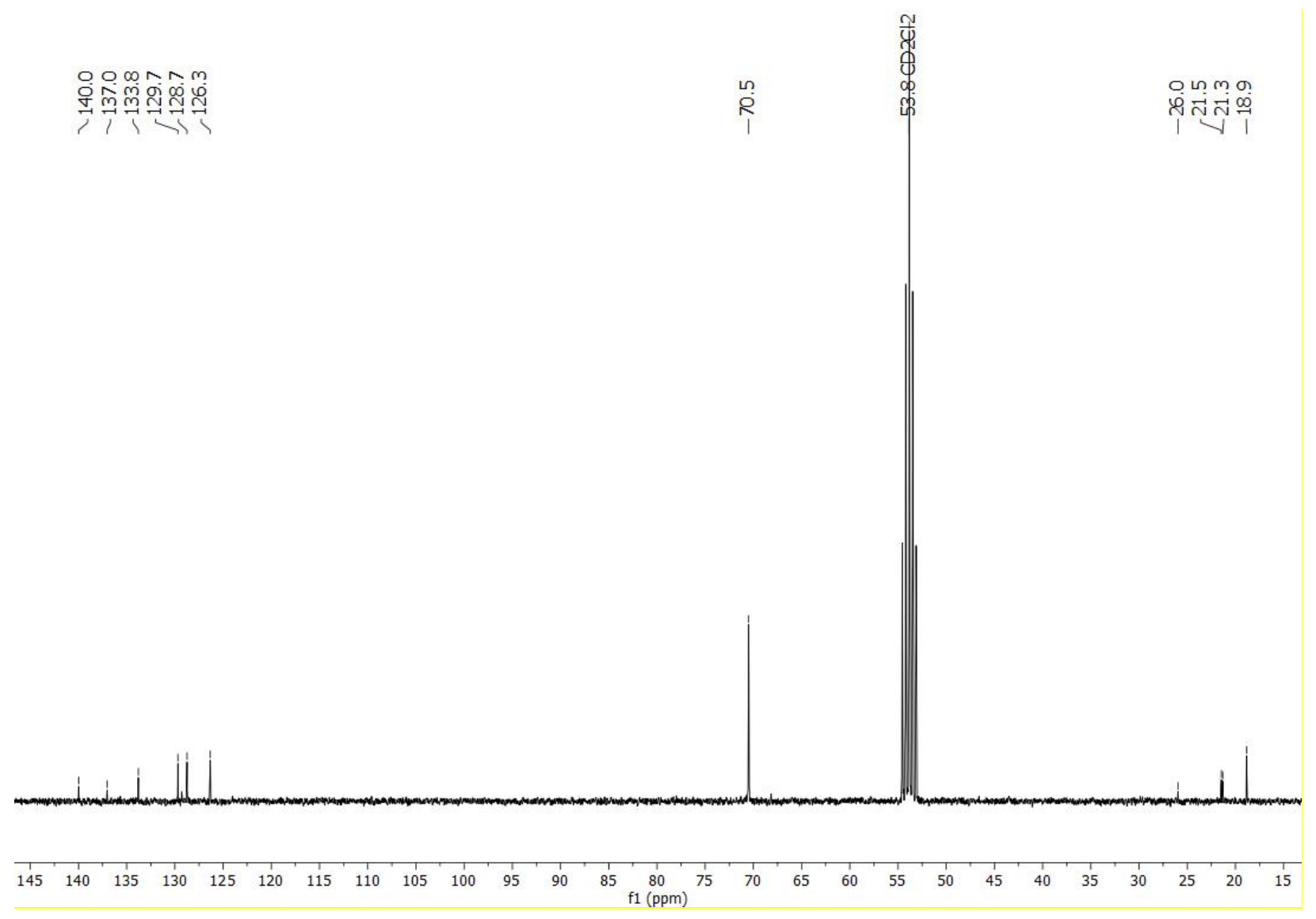

Figure S7. ${ }^{13} \mathrm{C}$ NMR spectrum of 3 dissolved in $\mathrm{CD}_{2} \mathrm{Cl}_{2}, 70.5 \mathrm{ppm}$ is assigned to $18-\mathrm{c}-6$. 


\subsection{EPR measurements}

\subsubsection{Reduction of 1 with sodium naphthalenide}

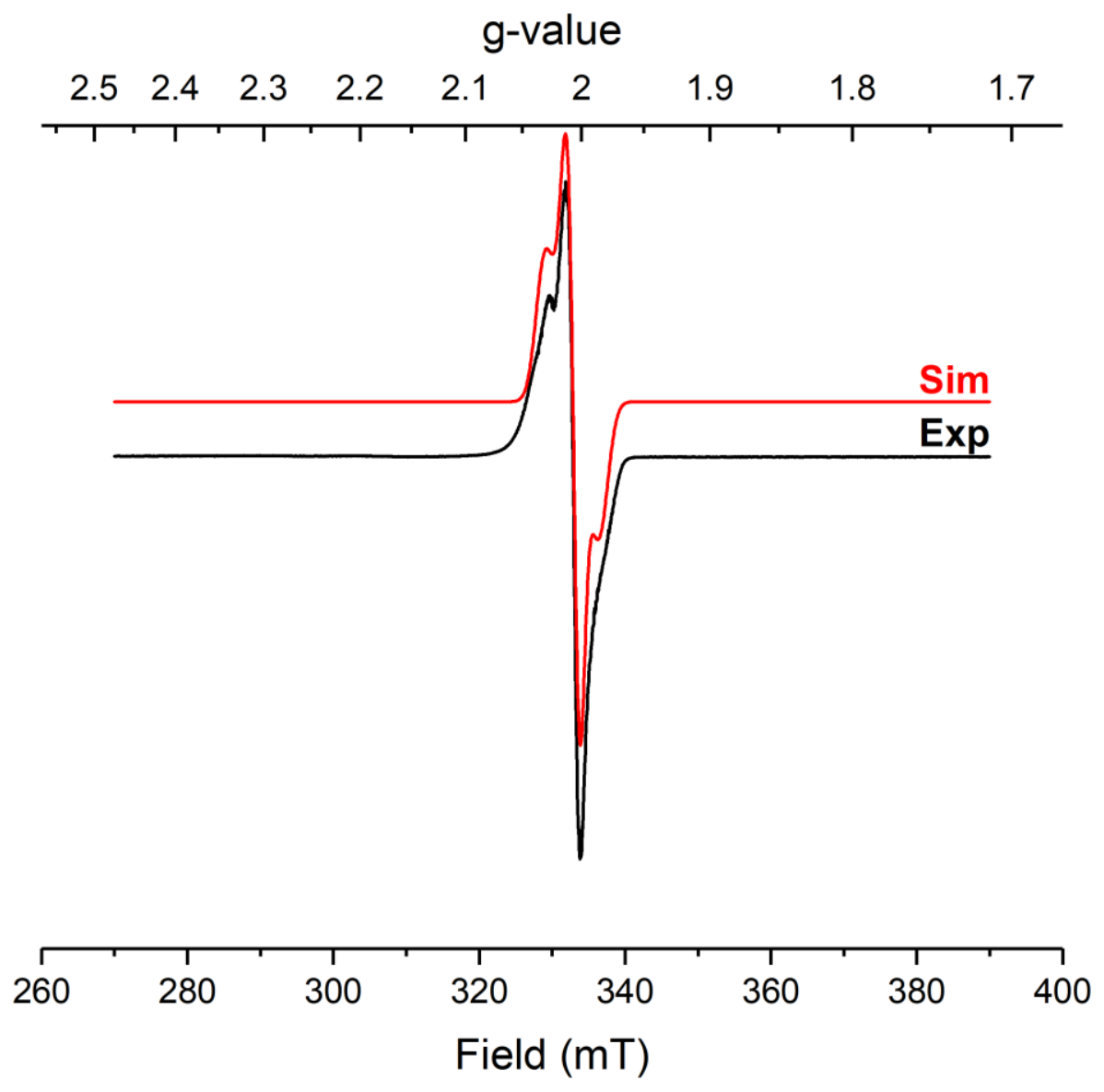

Figure S8. X-band EPR ( $77 \mathrm{~K}, 9.45 \mathrm{GHz})$ spectrum of a frozen solution of the reaction product $\left(1.0 \mathrm{mmol} \cdot \mathrm{L}^{-1}\right)$ of 1 with two equivalents of sodium naphthalenide in THF (black) and powder simulation for $\mathrm{g}=2.004,2.008,2.013$ (red). 


\subsubsection{Reaction of 2 with $\mathrm{O}_{2}$}
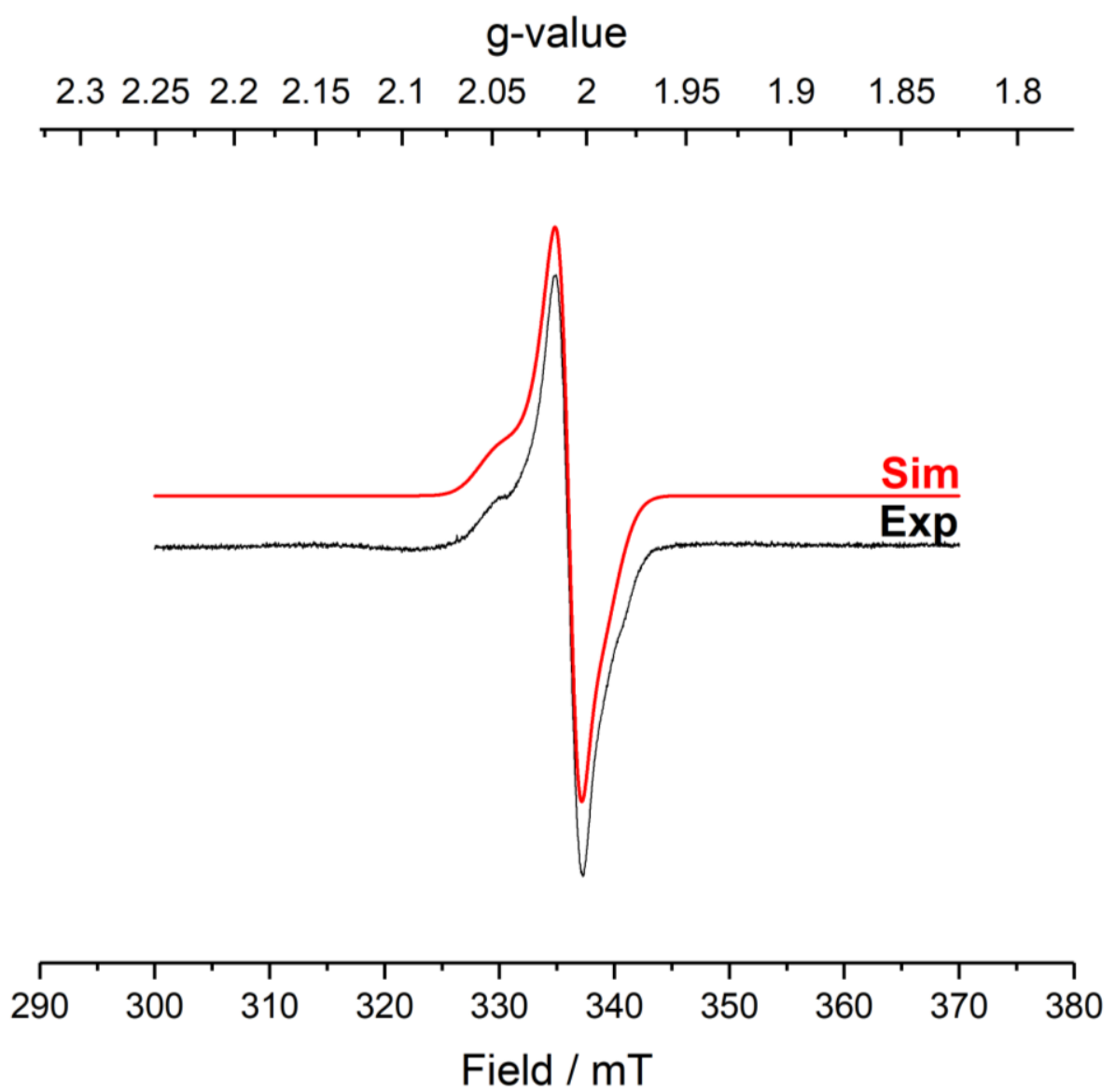

Figure S9. X-band EPR ( $77 \mathrm{~K}, 9.45 \mathrm{GHz})$ spectrum of a frozen solution of the reaction mixture of $2\left(0.5 \mathrm{mmol} \cdot \mathrm{L}^{-1}\right)$ with $\mathrm{O}_{2}$ at r.t. in toluene (black) and powder simulation for $\mathrm{g}=2.045,2.009$, 2.004 (red). 


\subsubsection{Reaction of 2 with 2,4,6-tri-tert-butylphenol (TTBP) in presence of $\mathrm{O}_{2}$}

A solution of $2\left(0.5 \mathrm{mmol} \cdot \mathrm{L}^{-1}\right)$ and TTBP $\left(12.5 \mathrm{mmol} \cdot \mathrm{L}^{-1}\right)$ in THF was treated with dioxygen at r.t. for $30 \mathrm{~min}$. Afterwards an aliquot was transferred into an EPR tube, which was then frozen immediately in liquid dinitrogen.

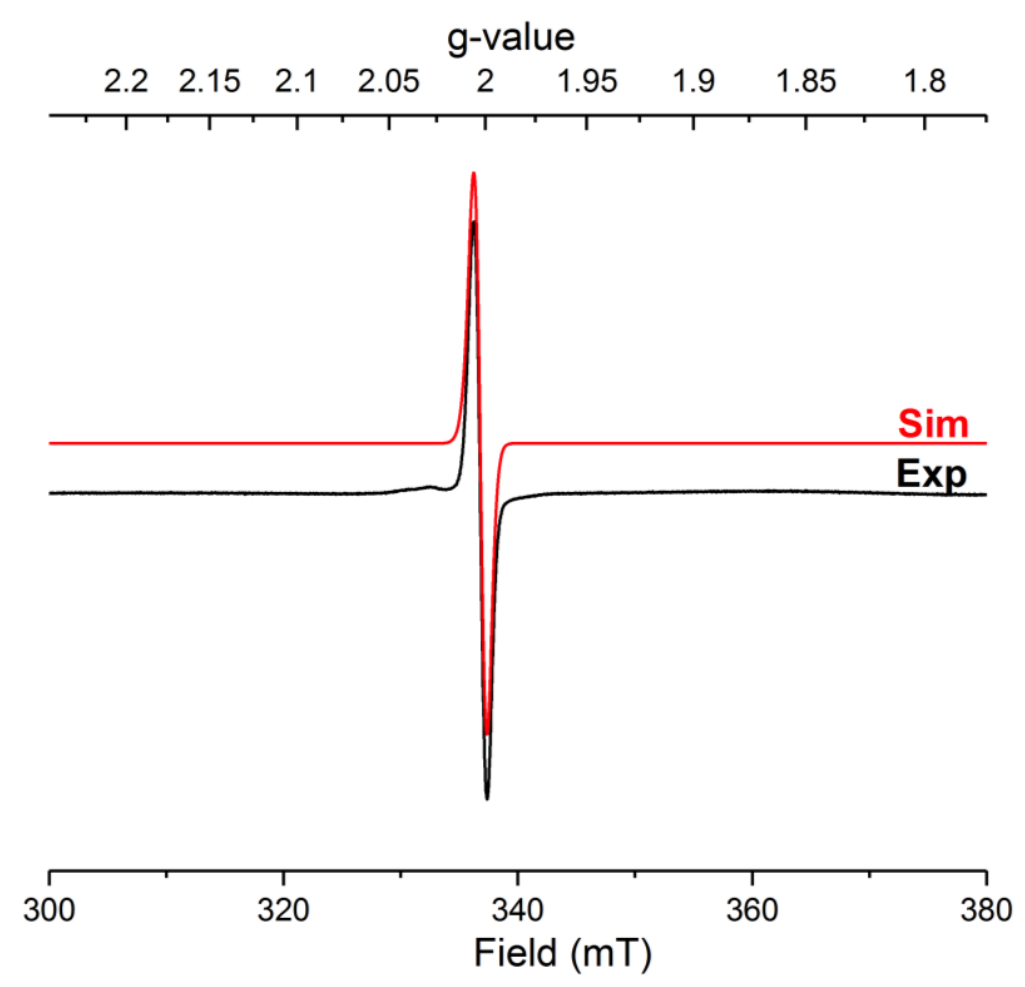

Figure S10. X-band EPR ( $77 \mathrm{~K}, 9.45 \mathrm{GHz})$ spectrum of a frozen solution containing the 2,4,6-tri$t$-butylphenoxyl radical generated by treating TTBP with $2\left(0.5 \mathrm{mmol} \cdot \mathrm{L}^{-1}\right)$ in the presence of $\mathrm{O}_{2}$ in THF at r.t. (black) and powder simulation for $\mathrm{g}=2.003,2.006,2.004$ (red). 


\subsubsection{Reaction of 2 with TEMPO-H in presence of $\mathrm{O}_{2}$}

A solution of $2\left(0.5 \mathrm{mmol} \cdot \mathrm{L}^{-1}\right)$ and TEMPO-H $\left(25 \mathrm{mmol} \cdot \mathrm{L}^{-1}\right)$ in toluene was treated with dioxygen at r.t. for $30 \mathrm{~min}$. Afterwards an aliquot was transferred into an EPR tube which was then frozen immediately in liquid dinitrogen.

\begin{tabular}{|c|c|c|c|c|c|c|c|c|}
\hline \multicolumn{9}{|c|}{ g-value } \\
\hline 2.25 & 2.2 & 2.15 & 2.1 & 2.05 & 2 & 1.95 & 1.9 & 1.85 \\
\hline
\end{tabular}

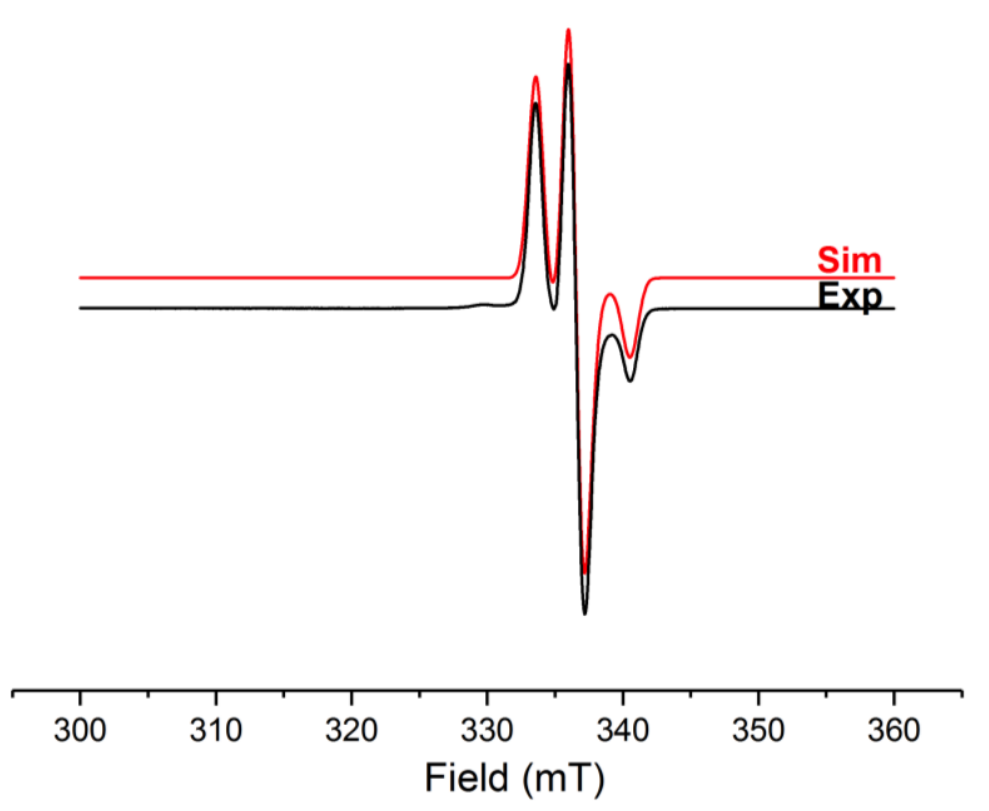

Figure S11. X-band EPR spectrum $(77 \mathrm{~K}, 9.45 \mathrm{GHz})$ of a frozen solution containing the TEMPO radical generated by reaction of TEMPO-H with $2\left(0.5 \mathrm{mmol} \cdot \mathrm{L}^{-1}\right)$ in presence of $\mathrm{O}_{2}$ in toluene at r.t. (black) and powder simulation for $\mathrm{g}=2.006,2.010,2.002$ (red). 


\subsubsection{Reaction of 2 with $\mathrm{PPh}_{3}$ in presence of $\mathrm{O}_{2}$}

$7.2 \mathrm{mg}$ of 2 (1 eq., $8.05 \mu \mathrm{mol})$ and $4.2 \mathrm{mg}$ of $\mathrm{PPh}_{3}(2$ eq., $16.1 \mu \mathrm{mol})$ were dissolved in $8 \mathrm{~mL}$ toluene and dioxygen was bubbled into the solution for $30 \mathrm{~s}$. Aliquots were transferred after 1.5 min, $16 \mathrm{~min}, 27 \mathrm{~min}, 37 \mathrm{~min}, 47 \mathrm{~min}$ and 15 hours into an EPR tube and then frozen immediately in liquid dinitrogen.

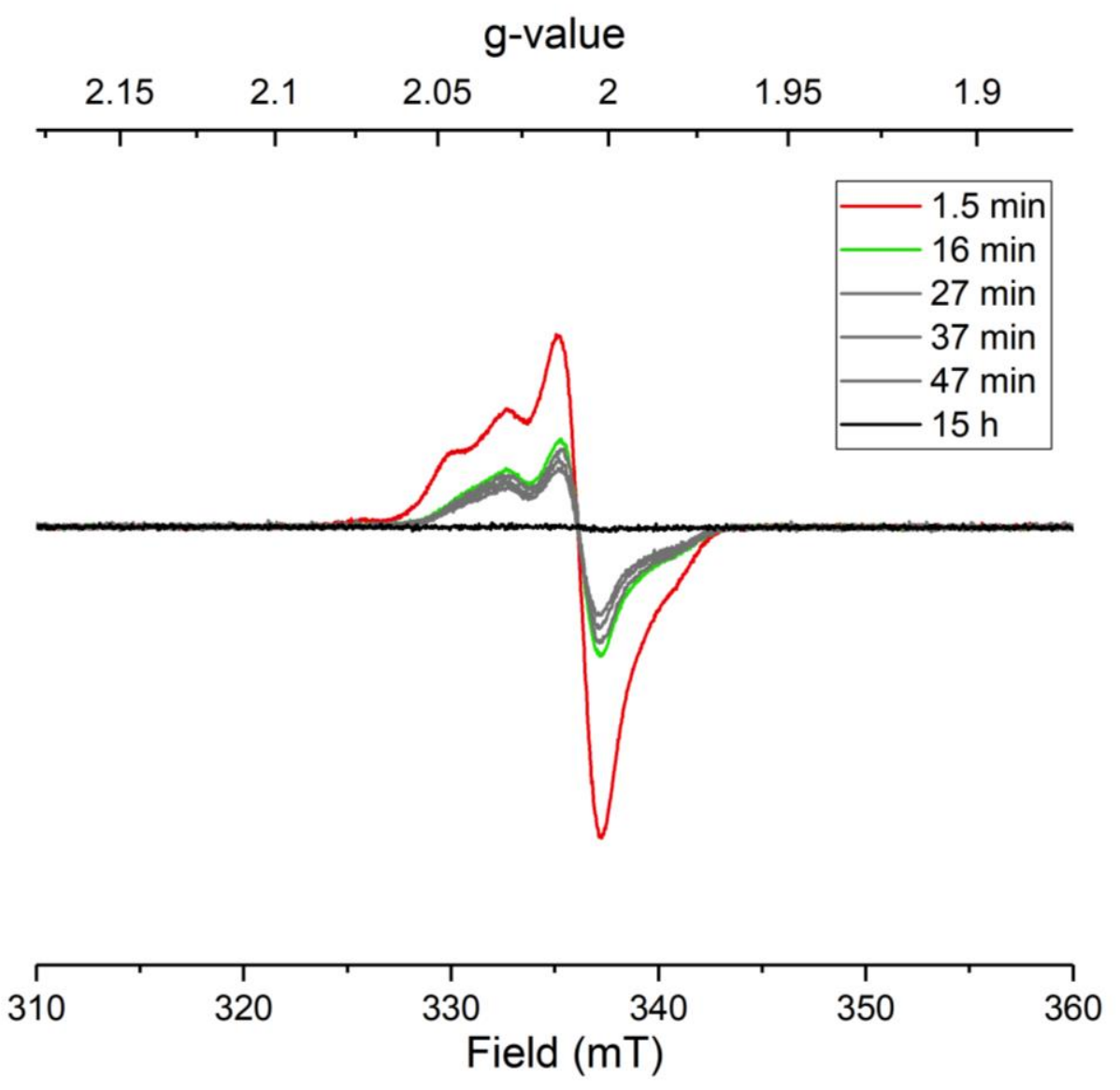

Figure S12. X-band EPR ( $77 \mathrm{~K}, 9.45 \mathrm{GHz})$ spectrum of a frozen aliquot of the reaction mixture of $2\left(1 \mathrm{mmol} \cdot \mathrm{L}^{-1}\right)$ in presence of $\mathrm{O}_{2}$ and $\mathrm{PPh}_{3}\left(2 \mathrm{mmol} \cdot \mathrm{L}^{-1}\right)$ in toluene monitored within the given time intervals. The EPR signal is decreasing with time and has completely disappeared after 15 hours. 


\subsection{GC measurements}

\subsubsection{Reaction of 2 with Cyclohexene in presence of $\mathrm{O}_{2}$}

$2.2 \mathrm{mg}$ of compound $2(2.47 \mu \mathrm{mol})$ suspended in $2 \mathrm{~mL}$ cyclohexene was treated with dioxygen through bubbling of $\mathrm{O}_{2}$ into the solution. The solution was stirred overnight for approximately 16 hours at r.t. The oxidation products were separated by vacuum transfer into a cold trap and identified by GC-MS. In $1 \mathrm{~mL}$ of sample $0.15 \mathrm{mg}$ biphenyl $(1 \mu \mathrm{mol})$ was dissolved as standard reference. 

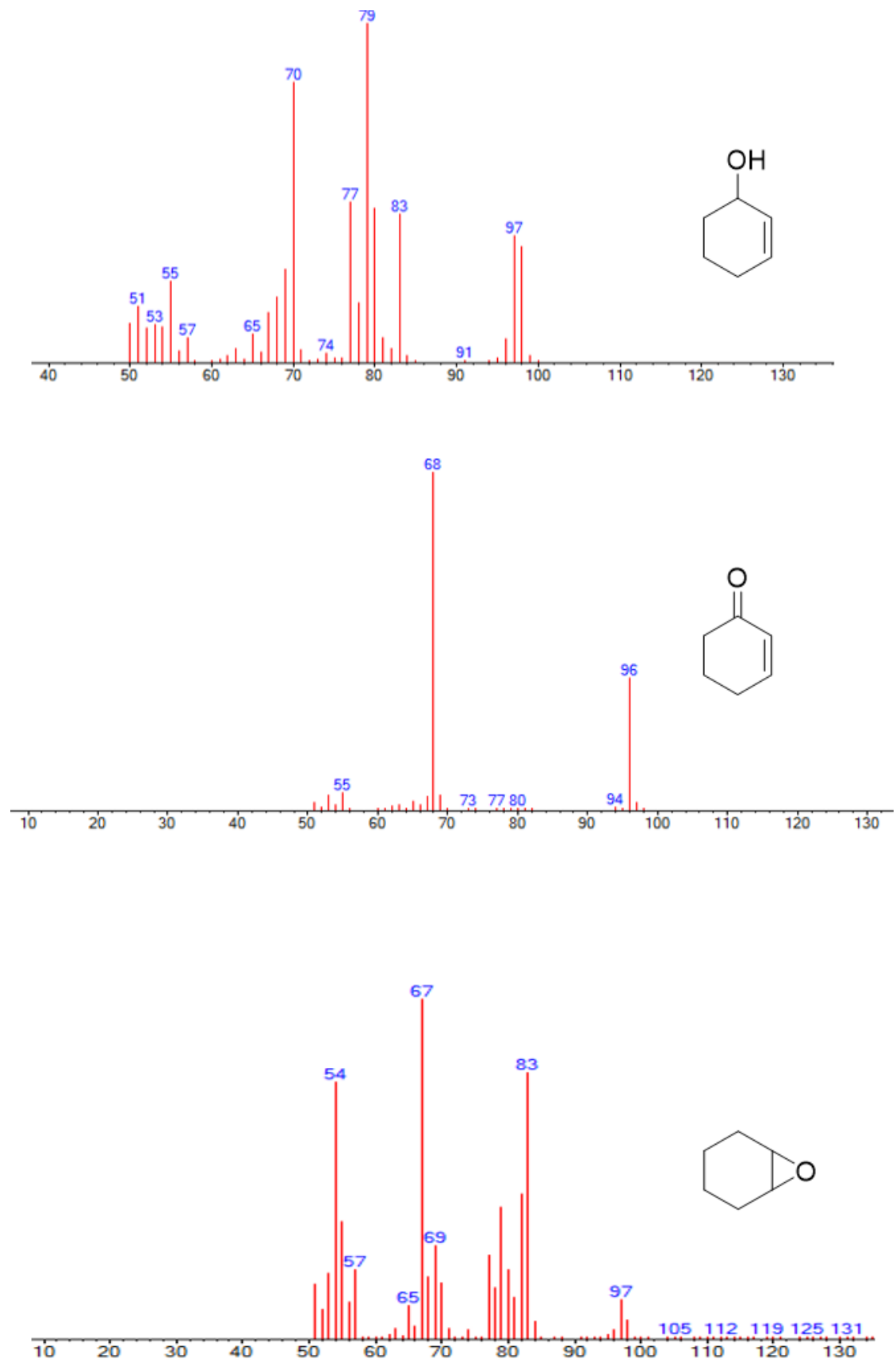

Figure S13. MS spectra of the oxidation products of cyclohexene generated by 2 in presence of $\mathrm{O}_{2}$. 


\subsection{UV/vis studies}

\subsubsection{Reaction of 2 with $\mathrm{O}_{2}$}

A $0.1 \mathrm{mmol} \cdot \mathrm{L}^{-1}$ solution of 2 in toluene was filled into a quartz cuvette and the $\mathrm{UV} / \mathrm{vis}$ spectrum determined. After 1 min $\mathrm{O}_{2}$ was bubbled with a balloon attached to a cannula into the solution. The green spectrum in Figure S7 was recorded $5 \mathrm{~min}$ after the addition of dioxygen and corresponds to the end of the conversion.

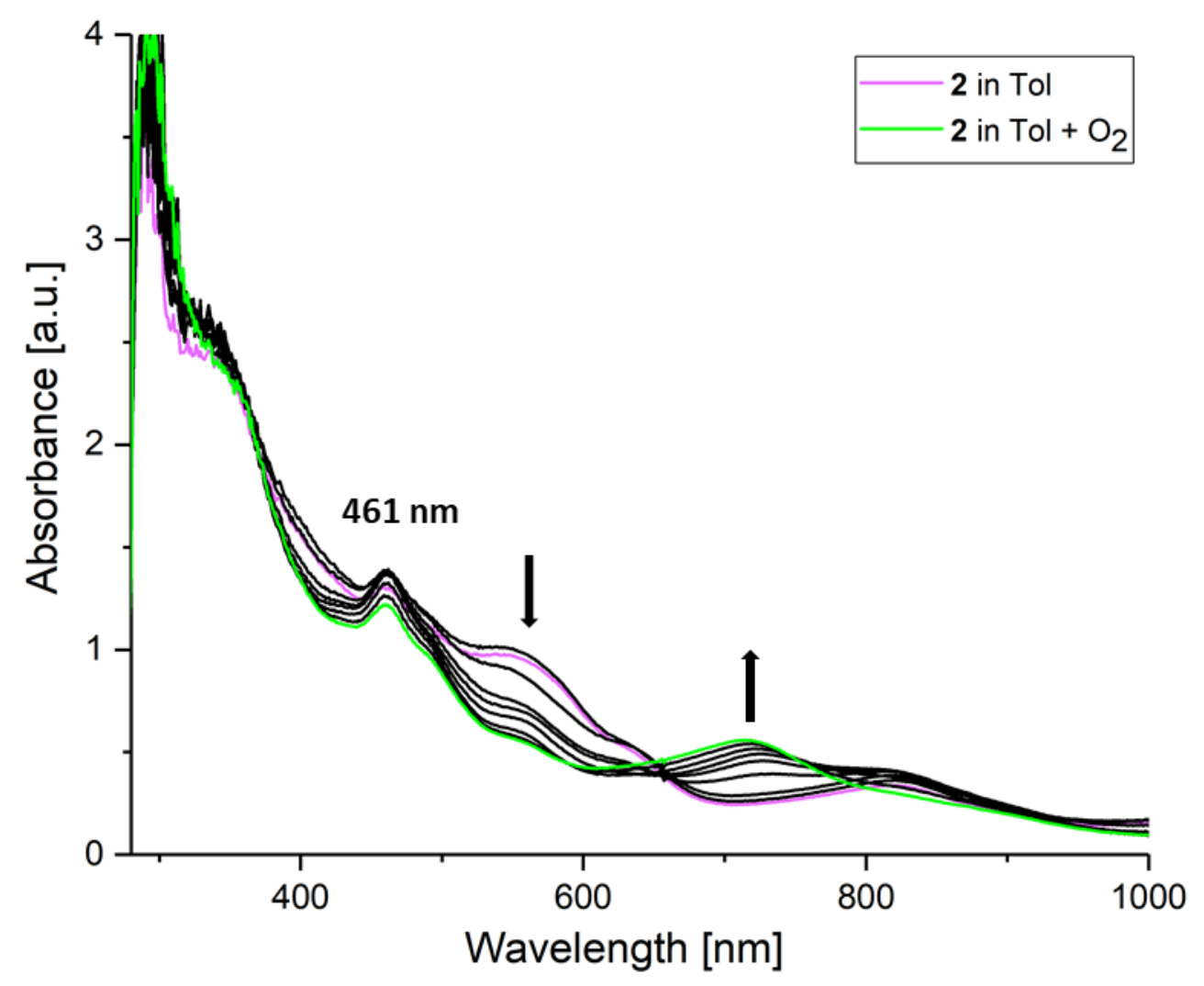

Figure S14. UV/vis spectrum of $2\left(0.1 \mathrm{mmol} \cdot \mathrm{L}^{-1}\right)$ before and after oxidation with $\mathrm{O}_{2}$ in toluene at $-80{ }^{\circ} \mathrm{C}$. In the course of oxidation, the band at $550 \mathrm{~nm}$ is diminishing and a new band at $716 \mathrm{~nm}$ is forming. After the addition of $\mathrm{O}_{2}$ the $\mathrm{UV} /$ vis spectra were recorded after 1.5, 2.0, 2.5, 3.7, 4.7 and 5.0 (green) min. 


\subsubsection{Reaction of 2 with 2,6-dimethylphenol (DMP) in presence of $\mathrm{O}_{2}$}

$2.8 \mathrm{~mL}$ toluene were filled into a quartz cuvette and $0.1 \mathrm{~mL}$ of a $3 \mathrm{mmol} \cdot \mathrm{L}^{-1}$ solution of 2 were added. A UV/vis spectrum was recorded at $-40{ }^{\circ} \mathrm{C}$. After the addition of $0.1 \mathrm{~mL}$ of a $150 \mathrm{mmol} \cdot \mathrm{L}^{-}$

${ }^{1}$ solution of 2,6-dimethylphenol $\mathrm{O}_{2}$ was bubbled through the solution via a balloon attached to a cannula.

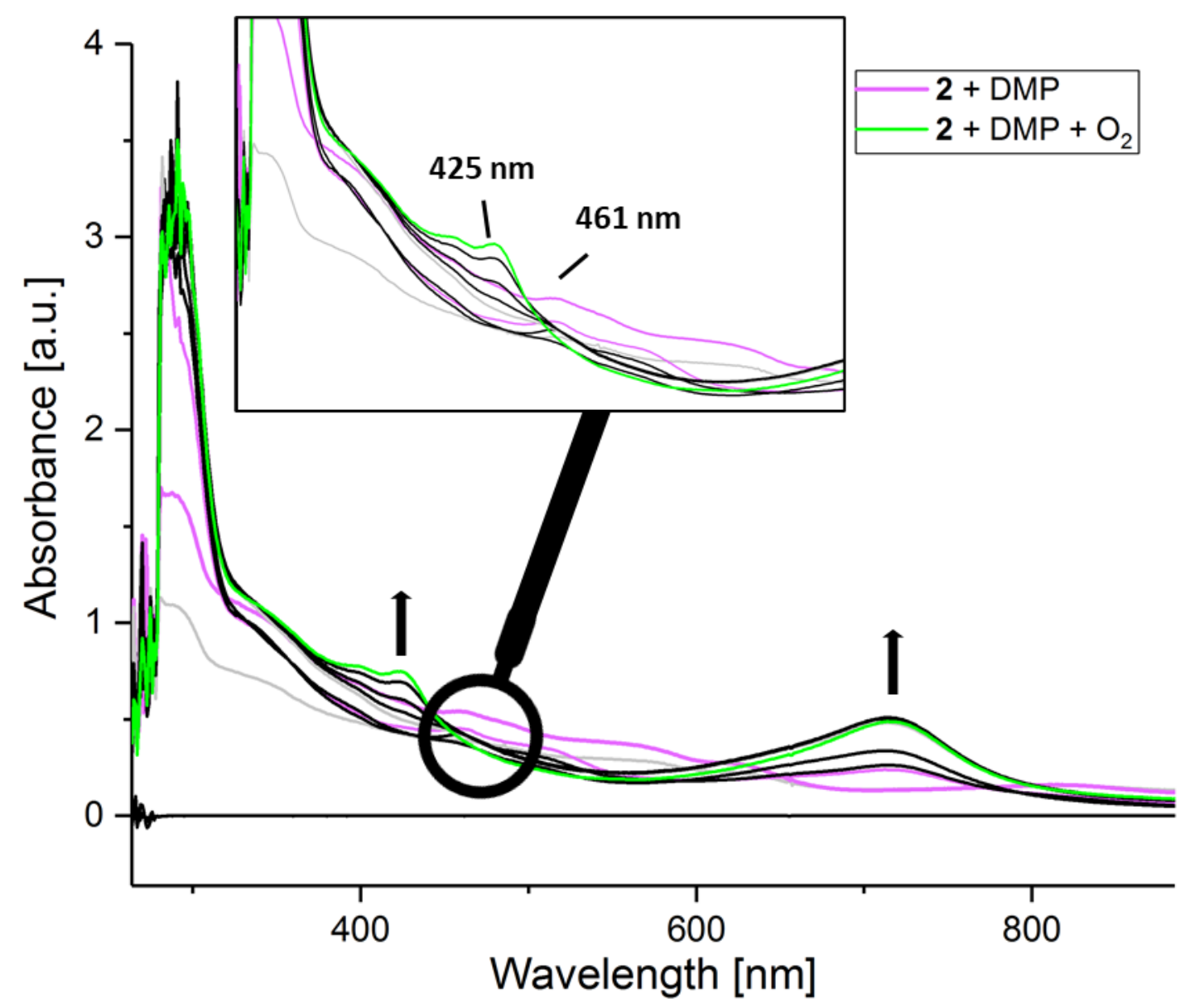

Figure S15. UV/vis spectra recorded for solutions of $2\left(0.1 \mathrm{mmol} \cdot \mathrm{L}^{-1}\right)$ and DMP $\left(50 \mathrm{mmol} \cdot \mathrm{L}^{-1}\right)$ in toluene at $-40^{\circ} \mathrm{C}$ and the proceedings after addition of $\mathrm{O}_{2}$. The bands at 425 and $716 \mathrm{~nm}$ evolve upon addition of $\mathrm{O}_{2}$. Die spectra were measured after 1.7, 5.5, 6.7, 7.5, 8.0, 10.0 (black) and 23 min (green) after the addition of $\mathrm{O}_{2}$. 


\subsubsection{Reaction of 2 with 2,6-di-tert-butylphenol (DTBP) in presence of $\mathrm{O}_{2}$}

a) $2.8 \mathrm{~mL}$ toluene were filled into a quartz cuvette and $0.1 \mathrm{~mL}$ of a $3 \mathrm{mmol} \cdot \mathrm{L}^{-1}$ solution of 2 were added. UV/vis spectra were recorded at $-80^{\circ} \mathrm{C}$. After the addition of $0.1 \mathrm{~mL}$ of a 150 $\mathrm{mmol} \cdot \mathrm{L}^{-1}$ solution of DTBP $\mathrm{O}_{2}$ was bubbled through the solution via a balloon attached to a cannula into the solution.

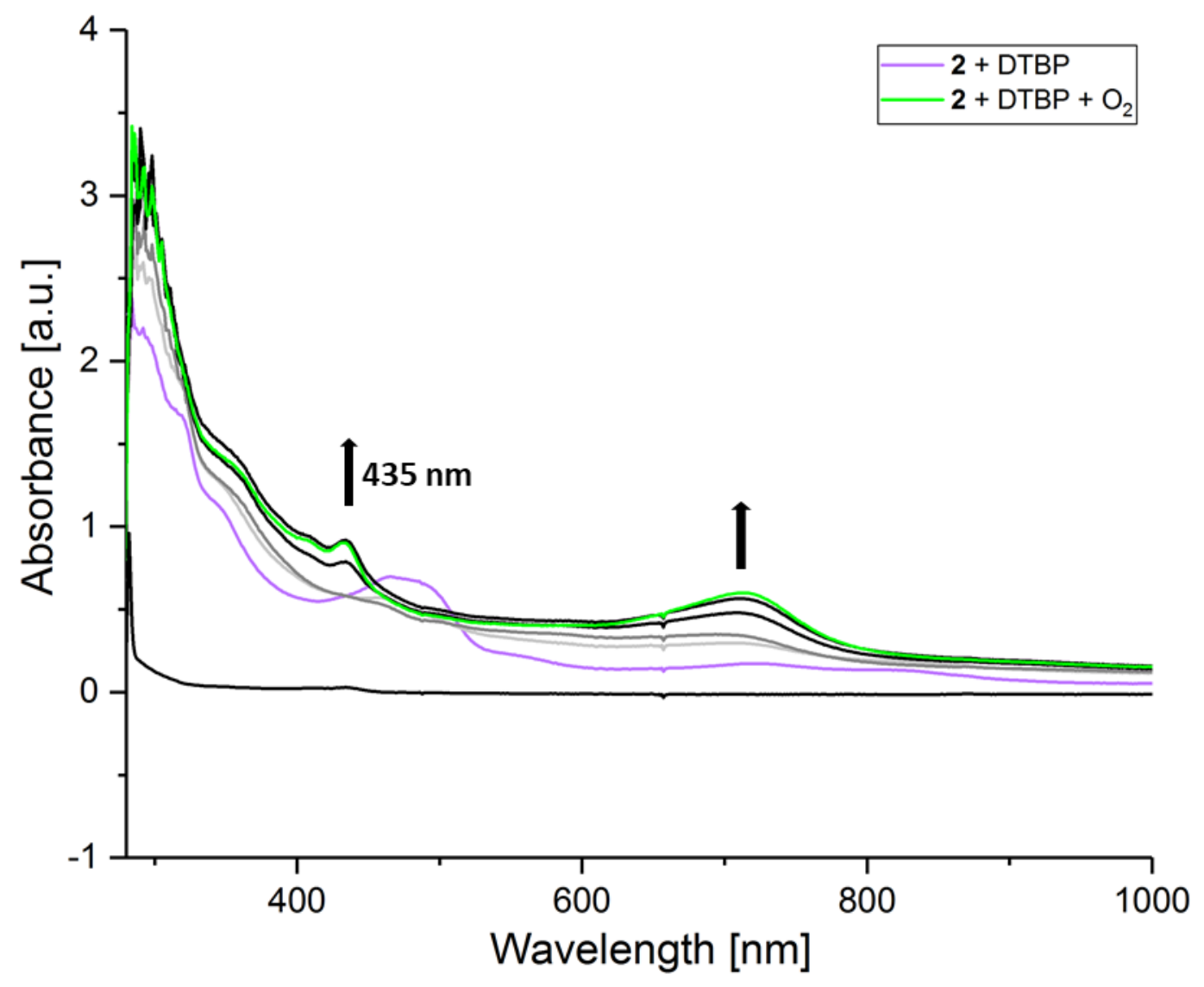

Figure S16. UV/vis spectra recorded for solutions of $2\left(0.1 \mathrm{mmol} \cdot \mathrm{L}^{-1}\right)$ and DTBP $\left(50 \mathrm{mmol} \cdot \mathrm{L}^{-1}\right)$ in toluene at $-80^{\circ} \mathrm{C}$ and the proceedings after addition of $\mathrm{O}_{2}$. The bands at 435 and $716 \mathrm{~nm}$ evolve upon addition of $\mathrm{O}_{2}$. First spectrum recorded after addition of $\mathrm{O}_{2}: 26$ seconds after the addition (grey), then 1.7, 27.5, 49 and 63 (green) $\mathrm{min}$. 
b) $2.8 \mathrm{~mL}$ of toluene saturated with $\mathrm{O}_{2}$ were filled into a quartz cuvette and $0.1 \mathrm{~mL}$ of a 150 $\mathrm{mmol} \cdot \mathrm{L}^{-1}$ solution of 2,6-di-tert-butylphenol was added. Subsequently, the addition of $0.1 \mathrm{~mL}$ of a $3 \mathrm{mmol} \cdot \mathrm{L}^{-1}$ solution of $\mathbf{2}$ took place.

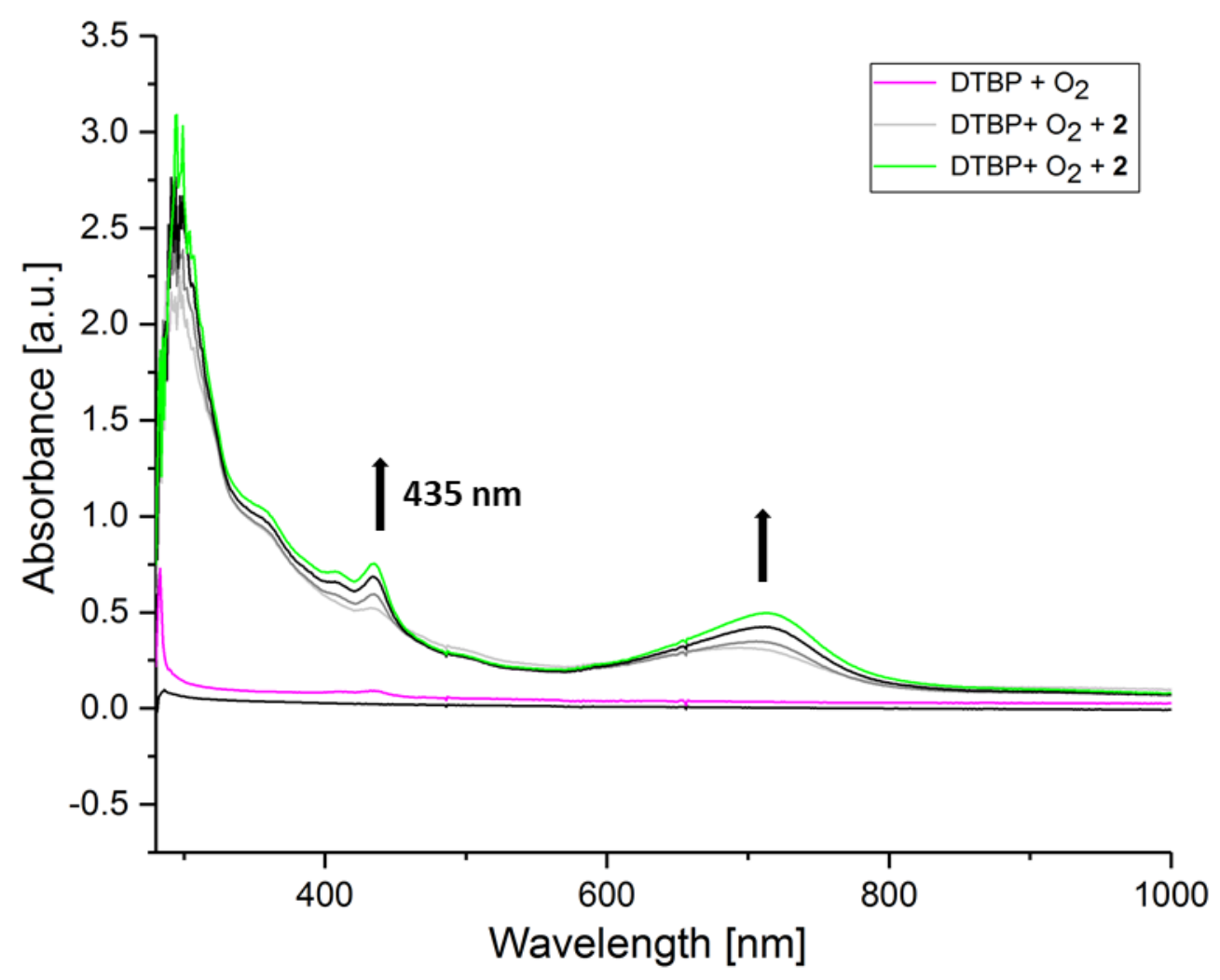

Figure S17. UV/vis spectrum of a DTBP $\left(50 \mathrm{mmol} \cdot \mathrm{L}^{-1}\right)$ solution in toluene in the presence of $\mathrm{O}_{2}$, before (pink) and after addition of $2\left(0.1 \mathrm{mmol} \cdot \mathrm{L}^{-1}\right)$ in toluene at $-80^{\circ} \mathrm{C}$ after $26 \mathrm{~s}$, $3.8 \mathrm{~min}, 11 \mathrm{~min}$ (black) and $22.5 \mathrm{~min}$ (green). 


\subsection{Cyclic voltammetry}

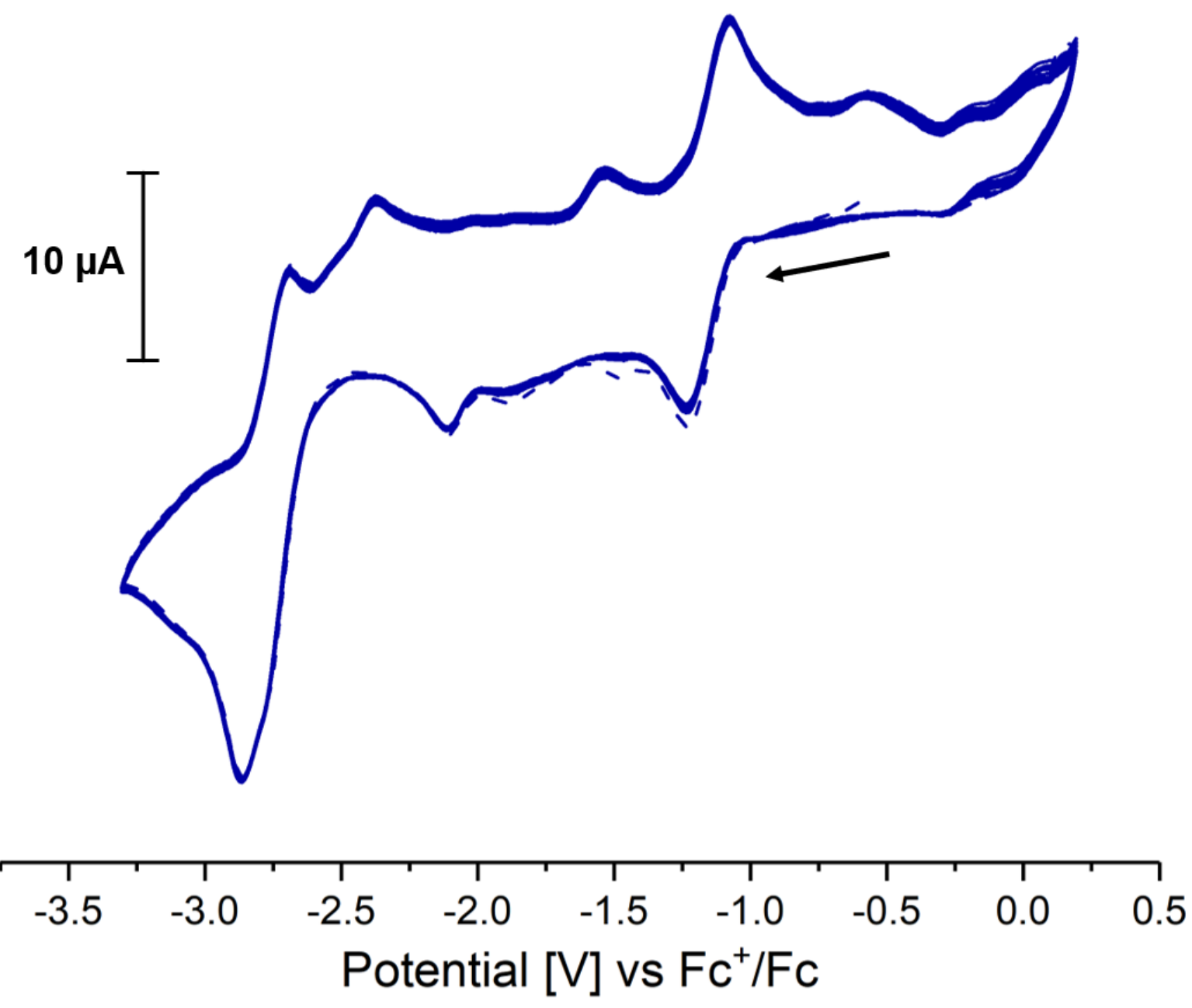

Figure S18. CV (10 cycles) of 1 dissolved in THF measured at a scan rate of $100 \mathrm{mV} / \mathrm{s}(100 \mathrm{mM}$ $\mathrm{TBAPF}_{6}, 1 \mathrm{mM}$ complex 1) at room temperature. Dotted line denotes the first scan. 


\section{Crystal Data}

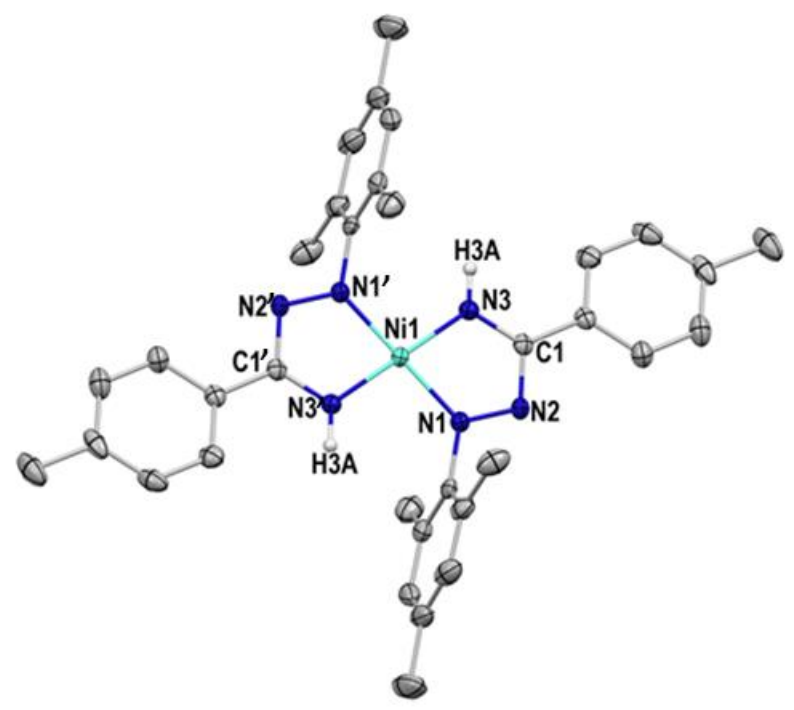

Figure S19. Molecular structure of $\mathbf{3}$ as determined by single crystal XRD. Hydrogen atoms are omitted for clarity. Selected bond lengths $[\AA]$ and angles $\left[^{\circ}\right]$ : Ni-N1 $1.8129(15), \mathrm{Ni}-\mathrm{N} 3$ 1.8225(15), N1-N2 1.337(2), N2-C1 1.352(2), N3-C1 1.331(2), N1-Ni-N1' 180.00(5), N3-NiN3' 180.0, N1-Ni-N3 81.50(7).

Table S1. Crystal data of $\mathbf{1} \cdot 3\left(\mathrm{C}_{4} \mathrm{H}_{8} \mathrm{O}\right), \mathbf{2} \cdot \mathrm{C}_{6} \mathrm{H}_{6}$, and $\mathbf{3}$

\begin{tabular}{|l|l|l|l|}
\hline & $\mathrm{LNi}(\mu-\mathrm{Br})_{2} \mathrm{NiL} \cdot 3\left(\mathrm{C}_{4} \mathrm{H}_{8} \mathrm{O}\right)$ & {$\left[\mathrm{L}{ }_{2} \mathrm{Ni}\right] \mathrm{K}(18-\mathrm{c}-6) \cdot \mathrm{C}_{6} \mathrm{H}_{6}$} & {$\left[\mathrm{~L}_{2}{ }_{2} \mathrm{Ni}\right]$} \\
\hline \multicolumn{1}{|c|}{$\mathrm{CCDC}$} & 2049784 & 2049783 & 2049782 \\
\hline Empirical formula & $\mathrm{C}_{52} \mathrm{H}_{58} \mathrm{Br}_{2} \mathrm{~N}_{8} \mathrm{Ni}_{2} \cdot 3\left(\mathrm{C}_{4} \mathrm{H}_{8} \mathrm{O}\right)$ & $\mathrm{C}_{34} \mathrm{H}_{38} \mathrm{~N}_{6} \mathrm{Ni} \cdot \mathrm{KC}_{12} \mathrm{H}_{24} \mathrm{O}_{6} \cdot \mathrm{C}_{6} \mathrm{H}_{6}$ & $\mathrm{C}_{34} \mathrm{H}_{38} \mathrm{~N}_{6} \mathrm{Ni}$ \\
\hline Formula weight & $1288.61 \mathrm{~g} \cdot \mathrm{mol}^{-1}$ & $970.93 \mathrm{~g} \cdot \mathrm{mol}^{-1}$ & $589.41 \mathrm{~g} \cdot \mathrm{mol}^{-1}$ \\
\hline Crystal system & monoclinic & monoclinic & monoclinic \\
\hline Space group & $P 2_{1} / \mathrm{c}$ & $C 2 / \mathrm{c}$ & $P 2_{1} / \mathrm{n}$ \\
\hline
\end{tabular}




\begin{tabular}{|c|c|c|c|}
\hline Unit cell dimensions & $\begin{array}{l}a=16.0796(11) \AA \\
b=27.7098(16) \AA \\
c=13.7838(10) \AA \\
\alpha=90^{\circ} \\
\beta=92.941(3)^{\circ} \\
\gamma=90^{\circ}\end{array}$ & $\begin{array}{l}a=14.517(9) \AA \\
b=23.845(10) \AA \\
c=15.890(7) \AA \\
\alpha=90^{\circ} \\
\beta=111.92(3)^{\circ} \\
\gamma=90^{\circ}\end{array}$ & $\begin{array}{l}a=9.083(2) \AA \\
b=13.420(3) \AA \\
c=12.894(3) \AA \\
\alpha=90^{\circ} \\
\beta=105.151(9)^{\circ} \\
\gamma=90^{\circ}\end{array}$ \\
\hline Volume & $6133.5(7) \AA^{3}$ & $5103(5) \AA^{3}$ & $1517.1(6) \AA^{3}$ \\
\hline$Z$ & 4 & 4 & 2 \\
\hline Density (calculated) & $1395 \mathrm{mg} \cdot \mathrm{m}^{-3}$ & $1264 \mathrm{mg} \cdot \mathrm{m}^{-3}$ & $1290 \mathrm{mg} \cdot \mathrm{m}^{-3}$ \\
\hline $\mathrm{F}(000)$ & 2688 & 2068 & 624 \\
\hline $\begin{array}{l}\text { Theta range for data } \\
\text { collection }\end{array}$ & $2.40^{\circ}$ to $25.24^{\circ}$ & $2.197^{\circ}$ to $25.405^{\circ}$ & $2.23^{\circ}$ to $25.24^{\circ}$ \\
\hline Reflections collected & 94590 & 44793 & 26527 \\
\hline $\begin{array}{l}\text { Independent } \\
\text { reflections }\end{array}$ & $10868\left(R_{\text {int }}=0.111\right)$ & $4688\left(R_{\mathrm{int}}=0.095\right)$ & $\begin{array}{l}2692\left(R_{\text {int }}=\right. \\
0.0366)\end{array}$ \\
\hline $\begin{array}{l}\text { Completeness } \\
\text { theta }=25.000^{\circ}\end{array}$ & $99.4 \%$ & $99.9 \%$ & $99.6 \%$ \\
\hline $\begin{array}{l}\text { Goodness-of-fit on } \\
\mathrm{F}^{2}\end{array}$ & 1.032 & 1.042 & 0.904 \\
\hline $\mathrm{R}$ indices (all data) & $\begin{array}{l}R_{1}=0.0691 \\
w R_{2}=0.0845\end{array}$ & $\begin{array}{l}R_{1}=0.0685 \\
w R_{2}=0.0925\end{array}$ & $\begin{array}{l}R_{1}=0.0359 \\
w R_{2}=0.0767\end{array}$ \\
\hline
\end{tabular}




\section{Density functional calculations}

Geometry optimizations were performed in redundant internal coordinates without symmetry restrictions using the Gaussian $16^{1}$ software packages. The B3LYP functional ${ }^{2-4}$ was employed, amended by the D3 version of Grimme's dispersion, ${ }^{5}$ together with the Def2-TZVP basis set, ${ }^{6,7}$ as implemented in Gaussian16. Very tight convergence criteria were chosen for the SCF procedure and a pruned $(99,590)$ "ultrafine" integration grid was used for numerical integrations.

\section{$\left[\mathbf{L}_{2}{ }_{2} \mathbf{N i}\right]^{-}$Anion}

The molecular structure of 2 [L'라이 $\mathrm{Ni} \mathrm{K}(18-\mathrm{c}-6)$ as determined by $\mathrm{X}$-ray diffraction analysis was used as starting point. The potassium cation and the crown ether were removed and the structure of the resulting anion was optimized in different spin states. Although no symmetry restrictions have been applied, the optimized structures had $\mathrm{C}_{\mathrm{i}}$ symmetry. Relative energies and spin densities of the doublet ground state (Fig. S12) and the quartet state are shown in Table S2.

Table S2: Relative energies and spin densities of optimized structures of the $\left[\mathrm{L}_{2}{ }_{2} \mathrm{Ni}\right]^{-}$anion.

\begin{tabular}{|c|c|c|}
\hline spin state & $\begin{array}{c}\text { relative energy } \\
(\mathbf{k J} / \mathbf{m o l})\end{array}$ & $\begin{array}{c}\text { Mulliken atomic spin } \\
\text { densities }\end{array}$ \\
\hline doublet & 0 & $\mathrm{Ni} 0.2, \mathrm{~L}^{1} 0.4, \mathrm{~L}^{2} 0.4$ \\
\hline quartet & 100.6 & $\mathrm{Ni} 1.6, \mathrm{~L}^{1} 0.7, \mathrm{~L}^{2} 0.7$ \\
\hline \multicolumn{2}{|c|}{$\mathrm{L}^{1}, \mathrm{~L}^{2}$ refers to the two ligand molecules. }
\end{tabular}




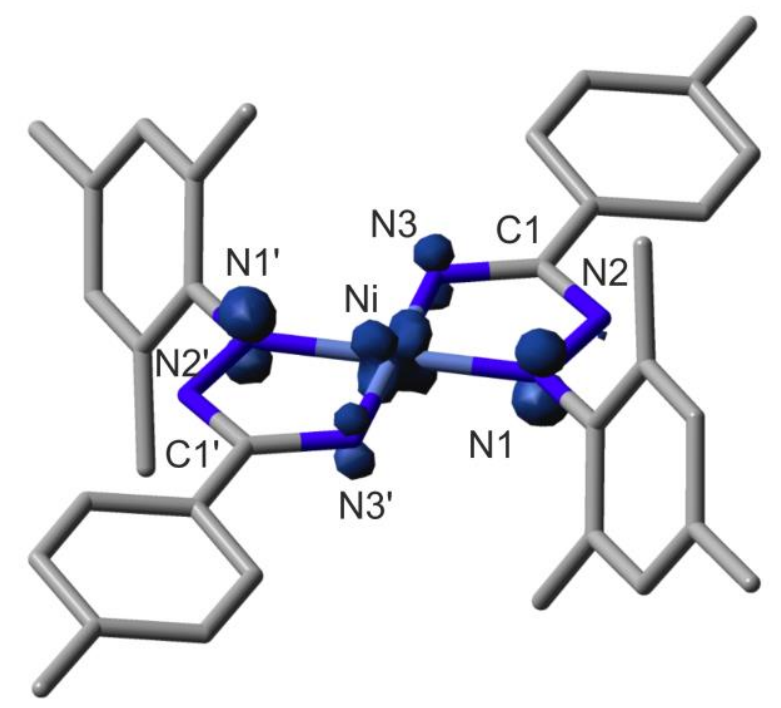

Figure S20. Spin density distribution calculated for the doublet ground state of the [L' $\left.{ }_{2} \mathrm{Ni}\right]$ anion (B3LYP-D3/Def2-TZVP). Hydrogen atoms are omitted for clarity. Selected bond lengths [ $\AA$ ] and angles [ $\left.{ }^{\circ}\right]$ : Ni-N3 1.852, Ni-N1 1.864, N1-N2 1.352, N2-C1 1.321, N3-C1 1.348; N3-Ni-N3' 180.0, N3-Ni-N1' 99.1, N3-Ni-N1 80.9, N2-C1-N3 117.5.

\section{L'2Ni (neutral)}

With one electron omitted, the optimized structure of the $\left[\mathrm{L}_{2}{ }_{2} \mathrm{Ni}\right]^{-}$anion served as starting point for the optimization of the neutral $\mathrm{L}_{2} \mathrm{Ni}$ complex 3. Relative energies and spin densities of different spin states are shown in Table S4. 
Table S3: Relative energies and spin densities of optimized structures of neutral [L $\left.{ }_{2} \mathrm{Ni}\right]$.

\begin{tabular}{|c|c|c|}
\hline spin state & $\begin{array}{c}\text { relative energy } \\
(\mathbf{k J} / \mathbf{m o l})\end{array}$ & $\begin{array}{c}\text { Mulliken atomic spin } \\
\text { densities }\end{array}$ \\
\hline closed-shell singlet & 9.7 & 0 \\
\hline open-shell singlet & 0 & $\mathrm{Ni} 0.0, \mathrm{~L}^{1}+0.75, \mathrm{~L}^{2}-0.75$ \\
\hline triplet & 21.4 & $\mathrm{Ni} 0.1, \mathrm{~L}^{1}+0.95, \mathrm{~L}^{2}+0.95$ \\
\hline
\end{tabular}

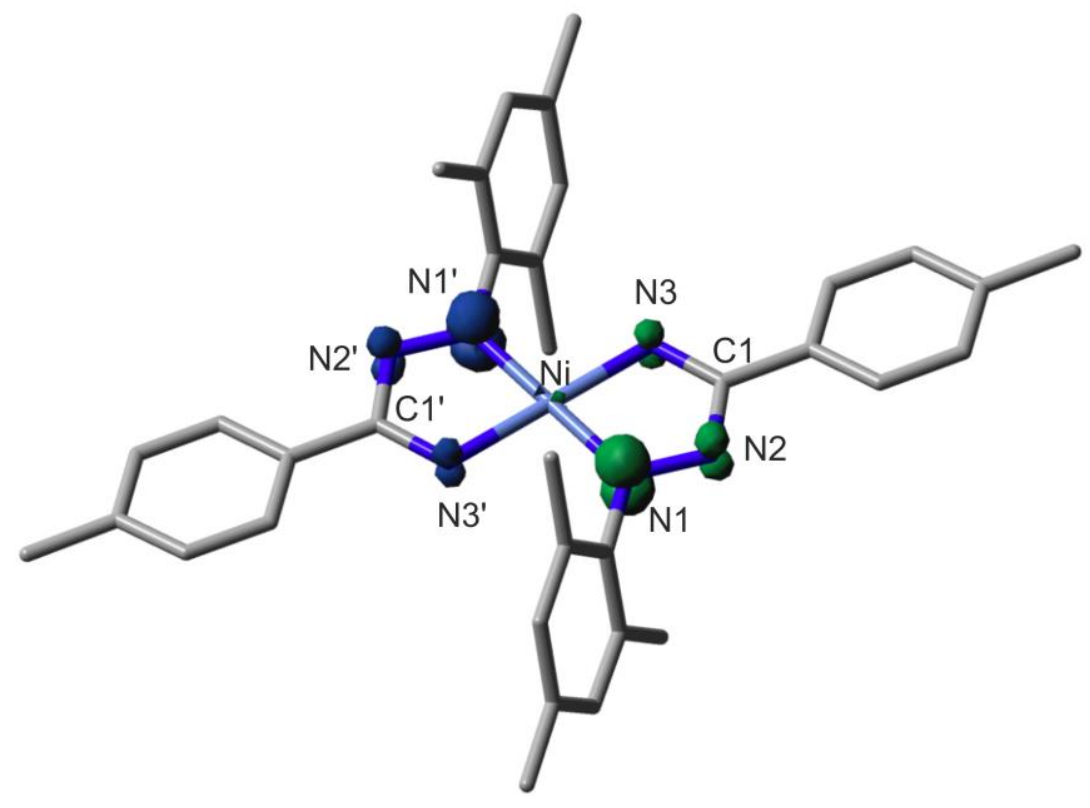

Figure S21. Spin density distribution calculated for the open-shell singlet ground state of complex 3 (B3LYP-D3/Def2-TZVP). Hydrogen atoms are omitted for clarity. Selected bond lengths [A] and angles $\left[^{\circ}\right]$ : Ni-N3 1.852, Ni-N1 1.856, N1-N2 1.320, N2-C1 1.348, N3-C1 1.326; N3-NiN3' 180.0, N3-Ni-N1' 99.1, N3-Ni-N1 80.9, N2-C1-N3 116.8. 
Cartesian coordinates $(\AA)$ for the theoretical structure of the doublet ground state of the $\left[L_{2}{ }_{2}{ }^{-}\right]^{-}$anion:

B3LYP/Def2-TZVP, doublet state, $\mathrm{E}=-3156.23441713$ hartree

\begin{tabular}{|c|c|c|c|}
\hline & $\mathbf{x}$ & $\mathbf{Z}$ & \\
\hline $\mathrm{Ni}$ & 0.000000 & 0.000000 & 0.000000 \\
\hline $\mathrm{N}$ & 1.069071 & 1.172819 & 0.978539 \\
\hline $\mathrm{N}$ & -1.069071 & -1.172819 & -0.978539 \\
\hline $\mathrm{N}$ & 0.849232 & 2.496899 & 0.812815 \\
\hline $\mathrm{N}$ & -0.849232 & -2.496899 & -0.812815 \\
\hline $\mathrm{N}$ & -0.609138 & 1.603737 & -0.697795 \\
\hline $\mathrm{N}$ & 0.609138 & -1.603737 & 0.697795 \\
\hline $\mathrm{C}$ & 1.925305 & 0.830505 & 2.042002 \\
\hline $\mathrm{C}$ & -1.925305 & -0.830505 & -2.042002 \\
\hline $\mathrm{C}$ & -0.047018 & 2.693582 & -0.137821 \\
\hline $\mathrm{C}$ & 0.047018 & -2.693582 & 0.137821 \\
\hline $\mathrm{C}$ & 1.535408 & 1.054929 & 3.374768 \\
\hline $\mathrm{C}$ & 3.148246 & 0.196789 & 1.763609 \\
\hline $\mathrm{C}$ & -1.535408 & -1.054929 & -3.374768 \\
\hline $\mathrm{C}$ & -3.148246 & -0.196789 & -1.763609 \\
\hline $\mathrm{C}$ & -0.389811 & 4.071100 & -0.516925 \\
\hline $\mathrm{C}$ & 0.389811 & -4.071100 & 0.516925 \\
\hline $\mathrm{C}$ & 2.380309 & 0.646833 & 4.403113 \\
\hline $\mathrm{C}$ & 0.196615 & 1.670738 & 3.670260 \\
\hline $\mathrm{C}$ & 3.958446 & -0.203578 & 2.825528 \\
\hline $\mathrm{C}$ & 3.577414 & -0.028663 & 0.338744 \\
\hline $\mathrm{C}$ & -2.380309 & -0.646833 & -4.403113 \\
\hline $\mathrm{C}$ & -0.196615 & -1.670738 & -3.670260 \\
\hline $\mathrm{C}$ & -3.958446 & 0.203578 & -2.825528 \\
\hline $\mathrm{C}$ & -3.577414 & 0.028663 & -0.338744 \\
\hline $\mathrm{C}$ & 0.353830 & 5.158744 & -0.027904 \\
\hline $\mathrm{C}$ & -1.463036 & 4.359705 & -1.368582 \\
\hline $\mathrm{C}$ & -0.353830 & -5.158744 & 0.027904 \\
\hline $\mathrm{C}$ & 1.463036 & -4.359705 & 1.368582 \\
\hline $\mathrm{C}$ & 3.596752 & 0.014994 & 4.151980 \\
\hline $\mathrm{C}$ & -3.596752 & -0.014994 & -4.151980 \\
\hline $\mathrm{C}$ & 0.036552 & 6.458239 & -0.379386 \\
\hline $\mathrm{C}$ & -1.772047 & 5.669826 & -1.720386 \\
\hline $\mathrm{C}$ & -0.036552 & -6.458239 & 0.379386 \\
\hline $\mathrm{C}$ & 1.772047 & -5.669826 & 1.720386 \\
\hline $\mathrm{C}$ & 4.505749 & -0.391841 & 5.283921 \\
\hline $\mathrm{C}$ & -4.505749 & 0.391841 & -5.283921 \\
\hline $\mathrm{C}$ & -1.032165 & 6.744821 & -1.237628 \\
\hline $\mathrm{C}$ & 1.032165 & -6.744821 & 1.237628 \\
\hline $\mathrm{C}$ & -1.350932 & 8.164993 & -1.625615 \\
\hline $\mathrm{C}$ & 1.350932 & -8.164993 & 1.625615 \\
\hline $\mathrm{H}$ & -1.225425 & 1.739219 & -1.484377 \\
\hline $\mathrm{H}$ & 1.225425 & -1.739219 & 1.484377 \\
\hline
\end{tabular}




\begin{tabular}{lrrc}
$\mathrm{H}$ & 2.068727 & 0.807007 & 5.431180 \\
$\mathrm{H}$ & -0.037877 & 1.608805 & 4.734476 \\
$\mathrm{H}$ & -0.583413 & 1.159178 & 3.100415 \\
$\mathrm{H}$ & 0.165996 & 2.715211 & 3.356696 \\
$\mathrm{H}$ & 4.903885 & -0.690759 & 2.606804 \\
$\mathrm{H}$ & 2.918400 & -0.743301 & -0.156689 \\
$\mathrm{H}$ & 4.603169 & -0.399924 & 0.294651 \\
$\mathrm{H}$ & 3.508594 & 0.898414 & -0.233247 \\
$\mathrm{H}$ & -2.068727 & -0.807007 & -5.431180 \\
$\mathrm{H}$ & 0.037877 & -1.608805 & -4.734476 \\
$\mathrm{H}$ & 0.583413 & -1.159178 & -3.100415 \\
$\mathrm{H}$ & -0.165996 & -2.715211 & -3.356696 \\
$\mathrm{H}$ & -4.903885 & 0.690759 & -2.606804 \\
$\mathrm{H}$ & -2.918400 & 0.743301 & 0.156689 \\
$\mathrm{H}$ & -4.603169 & 0.399924 & -0.294651 \\
$\mathrm{H}$ & -3.508594 & -0.898414 & 0.233247 \\
$\mathrm{H}$ & 1.184431 & 4.952925 & 0.632978 \\
$\mathrm{H}$ & -2.081867 & 3.559105 & -1.753330 \\
$\mathrm{H}$ & -1.184431 & -4.952925 & -0.632978 \\
$\mathrm{H}$ & 2.081867 & -3.559105 & 1.753330 \\
$\mathrm{H}$ & 0.632402 & 7.274655 & 0.016790 \\
$\mathrm{H}$ & -2.612027 & 5.854381 & -2.381970 \\
$\mathrm{H}$ & -0.632402 & -7.274655 & -0.016790 \\
$\mathrm{H}$ & 2.612027 & -5.854381 & 2.381970 \\
$\mathrm{H}$ & 5.155448 & 0.434955 & 5.590327 \\
$\mathrm{H}$ & 5.151952 & -1.224124 & 4.997266 \\
$\mathrm{H}$ & 3.934574 & -0.696946 & 6.163792 \\
$\mathrm{H}$ & -5.155448 & -0.434955 & -5.590327 \\
$\mathrm{H}$ & -5.151952 & 1.224124 & -4.997266 \\
$\mathrm{H}$ & -3.934574 & 0.696946 & -6.163792 \\
$\mathrm{H}$ & -1.460892 & 8.805054 & -0.745492 \\
$\mathrm{H}$ & -2.278440 & 8.222352 & -2.198121 \\
$\mathrm{H}$ & -0.555814 & 8.599697 & -2.239824 \\
$\mathrm{H}$ & 1.460892 & -8.805054 & 0.745492 \\
$\mathrm{H}$ & 2.278440 & -8.222352 & 2.198121 \\
$\mathrm{H}$ & 0.555814 & -8.599697 & 2.239824 \\
\hline & & &
\end{tabular}


Cartesian coordinates $(\AA)$ for the theoretical structure of the open-shell singlet ground state of the neutral [ $\left.L{ }_{2} \mathrm{Ni}\right]$ :

B3LYP/Def2-TZVP, open-shell singlet state, $E=-3156.16545931$ hartree

\begin{tabular}{|c|c|c|c|}
\hline & $\mathbf{x}$ & $\mathbf{Z}$ & \\
\hline $\mathrm{Ni}$ & 0.000006 & -0.000002 & -0.000002 \\
\hline $\mathrm{N}$ & -0.436261 & 1.802127 & -0.088879 \\
\hline $\mathrm{N}$ & -1.714905 & 2.128086 & -0.091254 \\
\hline $\mathrm{N}$ & -1.845761 & -0.145729 & -0.043229 \\
\hline $\mathrm{N}$ & 0.436269 & -1.802131 & 0.088873 \\
\hline $\mathrm{N}$ & 1.714912 & -2.128095 & 0.091257 \\
\hline $\mathrm{N}$ & 1.845773 & 0.145721 & 0.043235 \\
\hline $\mathrm{C}$ & 0.487647 & 2.882523 & -0.067765 \\
\hline $\mathrm{C}$ & -2.480314 & 1.018159 & -0.071575 \\
\hline $\mathrm{C}$ & 0.703743 & 3.581625 & 1.126430 \\
\hline $\mathrm{C}$ & 1.224714 & 3.166067 & -1.223745 \\
\hline $\mathrm{C}$ & -3.942519 & 1.168823 & -0.079139 \\
\hline $\mathrm{C}$ & 1.672156 & 4.581591 & 1.137606 \\
\hline $\mathrm{C}$ & -0.071258 & 3.230299 & 2.366156 \\
\hline $\mathrm{C}$ & 2.184103 & 4.175162 & -1.163049 \\
\hline $\mathrm{C}$ & 0.975985 & 2.403228 & -2.496949 \\
\hline $\mathrm{C}$ & -4.526794 & 2.411365 & -0.357744 \\
\hline $\mathrm{C}$ & -4.789728 & 0.090062 & 0.193959 \\
\hline $\mathrm{C}$ & 2.421379 & 4.895235 & 0.005195 \\
\hline $\mathrm{C}$ & -5.903719 & 2.557460 & -0.371406 \\
\hline $\mathrm{C}$ & -6.168129 & 0.246106 & 0.177954 \\
\hline $\mathrm{C}$ & 3.439758 & 6.004610 & 0.037902 \\
\hline $\mathrm{C}$ & -6.752860 & 1.479367 & -0.108858 \\
\hline $\mathrm{C}$ & -8.247718 & 1.642870 & -0.158655 \\
\hline $\mathrm{C}$ & -0.487645 & -2.882520 & 0.067751 \\
\hline $\mathrm{C}$ & 2.480322 & -1.018170 & 0.071585 \\
\hline $\mathrm{C}$ & -0.703711 & -3.581646 & -1.126435 \\
\hline $\mathrm{C}$ & -1.224756 & -3.166024 & 1.223710 \\
\hline $\mathrm{C}$ & 3.942526 & -1.168838 & 0.079159 \\
\hline $\mathrm{C}$ & -1.672132 & -4.581603 & -1.137619 \\
\hline $\mathrm{C}$ & 0.071338 & -3.230358 & -2.366143 \\
\hline $\mathrm{C}$ & -2.184154 & -4.175109 & 1.163008 \\
\hline $\mathrm{C}$ & -0.976077 & -2.403130 & 2.496891 \\
\hline $\mathrm{C}$ & 4.526796 & -2.411383 & 0.357761 \\
\hline $\mathrm{C}$ & 4.789740 & -0.090078 & -0.193927 \\
\hline $\mathrm{C}$ & -2.421397 & -4.895211 & -0.005225 \\
\hline $\mathrm{C}$ & 5.903719 & -2.557483 & 0.371432 \\
\hline $\mathrm{C}$ & 6.168141 & -0.246126 & -0.177913 \\
\hline $\mathrm{C}$ & -3.439787 & -6.004575 & -0.037937 \\
\hline $\mathrm{C}$ & 6.752866 & -1.479391 & 0.108897 \\
\hline $\mathrm{C}$ & 8.247723 & -1.642899 & 0.158704 \\
\hline $\mathrm{H}$ & -2.397520 & -0.991511 & -0.071020 \\
\hline
\end{tabular}




\begin{tabular}{lrrr}
$\mathrm{H}$ & 1.853459 & 5.122624 & 2.060078 \\
$\mathrm{H}$ & 0.304837 & 3.776961 & 3.230544 \\
$\mathrm{H}$ & -0.002758 & 2.159352 & 2.572699 \\
$\mathrm{H}$ & -1.131264 & 3.457430 & 2.242328 \\
$\mathrm{H}$ & 2.756408 & 4.406024 & -2.055017 \\
$\mathrm{H}$ & 1.198299 & 1.342143 & -2.366789 \\
$\mathrm{H}$ & 1.589371 & 2.790672 & -3.310206 \\
$\mathrm{H}$ & -0.073079 & 2.468623 & -2.791571 \\
$\mathrm{H}$ & -3.884146 & 3.256029 & -0.561570 \\
$\mathrm{H}$ & -4.380154 & -0.880712 & 0.444159 \\
$\mathrm{H}$ & -6.331008 & 3.529490 & -0.590050 \\
$\mathrm{H}$ & -6.800485 & -0.605683 & 0.399666 \\
$\mathrm{H}$ & 2.971096 & 6.969491 & -0.176806 \\
$\mathrm{H}$ & 4.223451 & 5.849939 & -0.705212 \\
$\mathrm{H}$ & 3.911698 & 6.083841 & 1.018672 \\
$\mathrm{H}$ & -8.555685 & 2.609281 & 0.244438 \\
$\mathrm{H}$ & -8.755127 & 0.860378 & 0.406834 \\
$\mathrm{H}$ & -8.609941 & 1.591363 & -1.189733 \\
$\mathrm{H}$ & 2.397535 & 0.991500 & 0.071032 \\
$\mathrm{H}$ & -1.853410 & -5.122658 & -2.060083 \\
$\mathrm{H}$ & -0.304732 & -3.777037 & -3.230531 \\
$\mathrm{H}$ & 0.002857 & -2.159415 & -2.572714 \\
$\mathrm{H}$ & 1.131338 & -3.457498 & -2.242271 \\
$\mathrm{H}$ & -2.756498 & -4.405935 & 2.054961 \\
$\mathrm{H}$ & -1.198370 & -1.342047 & 2.366669 \\
$\mathrm{H}$ & -1.589506 & -2.790528 & 3.310136 \\
$\mathrm{H}$ & 0.072973 & -2.468524 & 2.791563 \\
$\mathrm{H}$ & 3.884143 & -3.256047 & 0.561577 \\
$\mathrm{H}$ & 4.380171 & 0.880699 & -0.444124 \\
$\mathrm{H}$ & 6.331004 & -3.529515 & 0.590074 \\
$\mathrm{H}$ & 6.800501 & 0.605662 & -0.399615 \\
$\mathrm{H}$ & -2.971145 & -6.969456 & 0.176815 \\
$\mathrm{H}$ & -4.223506 & -5.849874 & 0.705143 \\
$\mathrm{H}$ & -3.911692 & -6.083828 & -1.018723 \\
$\mathrm{H}$ & 8.555690 & -2.609308 & -0.244392 \\
$\mathrm{H}$ & 8.755138 & -0.860405 & -0.406777 \\
$\mathrm{H}$ & 8.609939 & -1.591398 & 1.189784 \\
\hline & & & \\
\hline
\end{tabular}




\section{References}

(1) M. J. Frisch, G. W. Trucks, H. B. Schlegel, G. E. Scuseria, M. A. Robb, J. R. Cheeseman, G. Scalmani, V. Barone, G. A. Petersson, H. Nakatsuji, X. Li, M. Caricato, A. V. Marenich, J. Bloino, B. G. Janesko, R. Gomperts, B. Mennucci, H. P. Hratchian, J. V. Ortiz, A. F. Izmaylov, J. L. Sonnenberg, Williams, F. Ding, F. Lipparini, F. Egidi, J. Goings, B. Peng, A. Petrone, T. Henderson, D. Ranasinghe, V. G. Zakrzewski, J. Gao, N. Rega, G. Zheng, W. Liang, M. Hada, M. Ehara, K. Toyota, R. Fukuda, J. Hasegawa, M. Ishida, T. Nakajima, Y. Honda, O. Kitao, H. Nakai, T. Vreven, K. Throssell, J. A. Montgomery Jr., J. E. Peralta, F. Ogliaro, M. J. Bearpark, J. J. Heyd, E. N. Brothers, K. N. Kudin, V. N. Staroverov, T. A. Keith, R. Kobayashi, J. Normand, K. Raghavachari, A. P. Rendell, J. C. Burant, S. S. Iyengar, J. Tomasi, M. Cossi, J. M. Millam, M. Klene, C. Adamo, R. Cammi, J. W. Ochterski, R. L. Martin, K. Morokuma, O. Farkas, J. B. Foresman and D. J. Fox, Gaussian 16 Rev. A.03, 2016.

(2) A. D. Becke, Density-functional exchange-energy approximation with correct asymptotic behavior, Phys. Rev. A, 1988, 38, 3098-3100.

(3) C. Lee, W. Yang and R. G. Parr, Development of the Colle-Salvetti correlation-energy formula into a functional of the electron density, Phys. Rev. B, 1988, 37, 785-789.

(4) A. D. Becke, Density-functional thermochemistry. III. The role of exact exchange, J. Chem. Phys., 1993, 98, 5648-5652.

(5) S. Grimme, S. Ehrlich and L. Goerigk, Effect of the damping function in dispersion corrected density functional theory, J. Comput. Chem., 2011, 32, 1456-1465.

(6) F. Weigend and R. Ahlrichs, Balanced basis sets of split valence, triple zeta valence and quadruple zeta valence quality for $\mathrm{H}$ to Rn: Design and assessment of accuracy, Phys. Chem. Chem. Phys., 2005, 7, 3297-3305.

(7) F. Weigend, Accurate Coulomb-fitting basis sets for H to Rn, Phys. Chem. Chem. Phys., 2006, $8,1057-1065$.

(8) NBO 7.0, E. D. Glendening, J. K. Badenhoop, A. E. Reed, J. E. Carpenter, J. A. Bohmann, C. M. Morales, P. Karafiloglou, C. R. Landis, F. Weinhold, Theoretical Chemistry Institute, University of Wisconsin, Madison, WI, 2018. 